University of South Florida

DIGITAL COMMONS

Digital Commons @ University of

@ UNIVERSITY OF SOUTH FLORIDA

South Florida

USF Accountability Reports

USF Archives

$1-1-2009$

\title{
2009 Annual Report USF Tampa
}

USF

Follow this and additional works at: https://digitalcommons.usf.edu/usf_accountability_reports

\section{Scholar Commons Citation}

USF, "2009 Annual Report USF Tampa" (2009). USF Accountability Reports. 5.

https://digitalcommons.usf.edu/usf_accountability_reports/5

This Article is brought to you for free and open access by the USF Archives at Digital Commons @ University of South Florida. It has been accepted for inclusion in USF Accountability Reports by an authorized administrator of Digital Commons @ University of South Florida. For more information, please contact digitalcommons@usf.edu. 


\title{
Florida Board of Governors State University System (SUS) Annual Report
}

\author{
University of South Florida-Tampa
}

Approved by the USF Board of Trustees

December 16, 2009

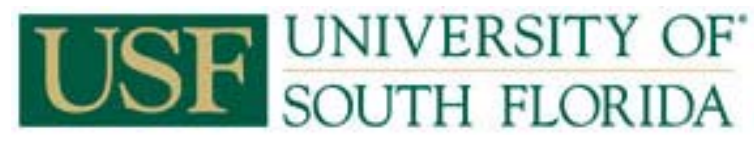




\section{$\underline{\text { Data Definitions }}$}

\section{GOAL 1:}

- Baccalaureate Degrees Awarded and Graduate Degrees Awarded: Graduate degrees include master's, research doctoral, and professional doctoral programs. Source: SUS Student Instruction File

\section{- \# and \% Baccalaureate Degrees Awarded (Non-Hispanic Blacks and Hispanics):} The number of baccalaureate degrees granted to non-Hispanic black students or Hispanic students. The percentage is the number of baccalaureate degrees awarded to each group divided by the total number of degrees awarded, excluding those awarded to non-resident aliens and those not reporting race/ethnicity. Source: SUS Student Instruction File

- \# and \% Baccalaureate Degrees Awarded (Pell Recipients): The number of baccalaureate degrees awarded to federal Pell grant recipients, an indicator of low family income. For this report, a Pell grant recipient is defined as a student who received Pell within six years of graduation. The percentage is the number of baccalaureate degrees awarded to Pell recipients as listed above divided by the total number of degrees awarded, excluding those awarded to non-resident aliens. Sources: SUS Student Instruction File and Student Financial Aid File

\section{GOAL 2:}

- \# Degrees Awarded in Select Areas of Strategic Emphasis: Degrees as reported above by six-digit Classification of Instruction Program. The areas of strategic emphasis were selected by the Board of Governors staff in consultation with business and industry groups.

- Pass Rates on Professional Licensure Examinations: Many professional licensure data, gathered by the respective licensing boards and housed within the Department of Business and Professional Regulation, are not currently formatted and do not contain sufficient information to match to SUS data. Board of Governors staff will work with individuals from the appropriate agencies to try to get data in the needed format.

\section{GOAL 3:}

- Federally Financed and Total Academic Research and Development Expenditures: The National Science Foundation conducts an annual survey of colleges and universities regarding research and development expenditures. These amounts combine reported science and engineering R\&D expenditures with reported nonscience and engineering expenditures. Dollars are in nominal dollars (i.e., not inflationadjusted). Source: http://webcaspar.nsf.gov/ 
- \# Licenses/Options Executed: Count of the number of licenses/options executed in the fiscal year for all technologies. Each license agreement is counted separately. Source: AUTM Licensing Survey

- Licensing Income Received: License issue fees, payments under options, annual minimums, running royalties, termination payments, amount of equity received when cashed-in, and software and biological material end-user license fees of $\$ 1,000$ or more, but not research funding, patent expense reimbursement, valuation of equity not cashed-in, software and biological material end-user license fees of less than $\$ 1,000$, or trademark licensing royalties from university insignia. Source: AUTM Licensing Survey

\section{$\underline{\text { RESOURCES, EFFICIENCIES, AND EFFECTIVENESS }}$}

\section{- 6 -Year Graduation and Retention Rates (FTICs), 4-Year Graduation and Retention Rates (AA Transfers), 5-Year Graduation and Retention Rates (Other Transfers): An} FTIC cohort is defined as undergraduates entering in fall term or summer continuing to fall with fewer than 12 hours earned since high school graduation. An AA Transfer cohort is defined as undergraduates entering in fall term or summer continuing to fall and having earned an AA degree from an institution in the Florida College System. An Other Transfer cohort is defined as undergraduates entering in fall term or summer continuing to fall who are not FTICs or AA transfers. The rate is the percentage of the initial cohort that had either graduated from or was still enrolled in the sixth academic year for FTIC students, fourth year for AA Transfers, and fifth year for Other Transfers. Both full-time and part-time students are included in the calculation. Source: SUS Retention File

- Student-Faculty Ratio: The ratio of full-time equivalent students (full-time plus 1/3 part time) to full-time equivalent instructional faculty (full time plus $1 / 3$ part time). In the ratio calculations, exclude both faculty and students in stand-alone graduate or professional programs such as medicine, law, veterinary, dentistry, social work, business, or public health in which faculty teach virtually only graduate-level students. This metric does not count undergraduate or graduate student teaching assistants as faculty. Source: Common Data Set/IPEDS

- Funding per FTE Student: E\&G appropriation and tuition revenues are divided by total student FTE. Only state-fundable credit hours are used. To allow for national comparisons, FTE for this metric uses the standard IPEDS definition of FTE, equal to 30 credit hours for undergraduates and 24 for graduates. Sources: Operating Budget, SUS Student Instruction File 


\begin{tabular}{|c|c|c|c|c|c|c|c|}
\hline \multicolumn{8}{|c|}{ The University of South Florida - Tampa Campus 2009 Annual Report } \\
\hline \multicolumn{3}{|c|}{ Sites and Campuses } & \multirow{2}{*}{\multicolumn{3}{|c|}{ Degree Programs Offered (2007-08) }} & & \\
\hline Enrollments & \# & $\%$ & & & & \multicolumn{2}{|r|}{ Carnegie Classification } \\
\hline $\begin{array}{c}\text { TOTAL } \\
\text { (Fall 2008) }\end{array}$ & 39,263 & -- & \multicolumn{2}{|l|}{ TOTAL } & 226 & $\begin{array}{c}\text { Undergraduate } \\
\text { Instructional Program: }\end{array}$ & $\begin{array}{l}\text { Balanced arts \& sciences/professions, high graduate } \\
\text { coexistence }\end{array}$ \\
\hline Black & 4,783 & $12 \%$ & \multicolumn{2}{|c|}{ Baccalaureate } & 88 & Graduate Instructional & 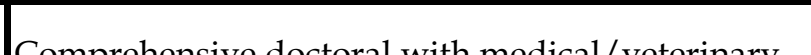 \\
\hline Hispanic & 5,277 & $13 \%$ & \multicolumn{2}{|c|}{ Master's \& Specialist's } & 97 & Program: & formprenensive aoctoral witn mearcal/ vererinary \\
\hline White & 24,656 & $63 \%$ & \multicolumn{2}{|c|}{ Research Doctorates } & 37 & Enrollment Profile: & High undergraduate \\
\hline Other & 4,547 & $12 \%$ & \multicolumn{2}{|c|}{ Professional Doctorates } & 4 & Undergraduate Profile: & $\begin{array}{l}\text { Medium full-time four-year, selective, higher } \\
\text { transfer-in }\end{array}$ \\
\hline Full-Time & 26,415 & $67 \%$ & \multirow{2}{*}{ Faculty (Fall 2008) } & \multirow{2}{*}{$\begin{array}{l}\text { Full- } \\
\text { Time }\end{array}$} & \multirow{2}{*}{$\begin{array}{l}\text { Part- } \\
\text { Time }\end{array}$} & Size and Setting: & Large four-year, primarily nonresidential \\
\hline Part-Time & 12,848 & $33 \%$ & & & & \multirow{2}{*}{ Basic: } & \multirow{2}{*}{ Research Universities (very high research activity) } \\
\hline Undergraduate & 29,492 & $75 \%$ & TOTAL & 1,388 & 210 & & \\
\hline Graduate & 8,101 & $21 \%$ & Tenure/T. Track & 969 & 78 & \multirow{2}{*}{ Elective Classification: } & Community Engagement: \\
\hline Unclassified & 1,670 & $4 \%$ & Non-Ten. Track & 419 & 132 & & Outreach \& Partnerships \\
\hline
\end{tabular}

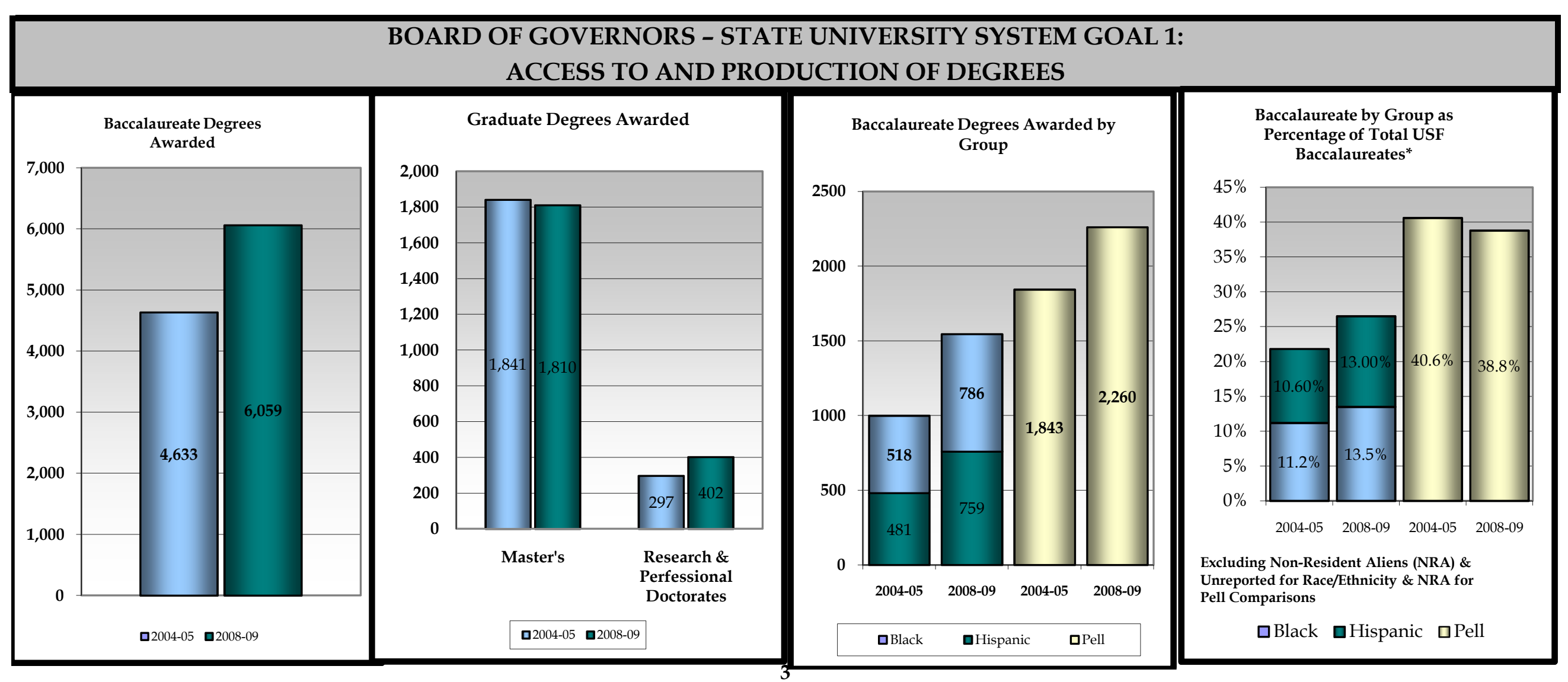




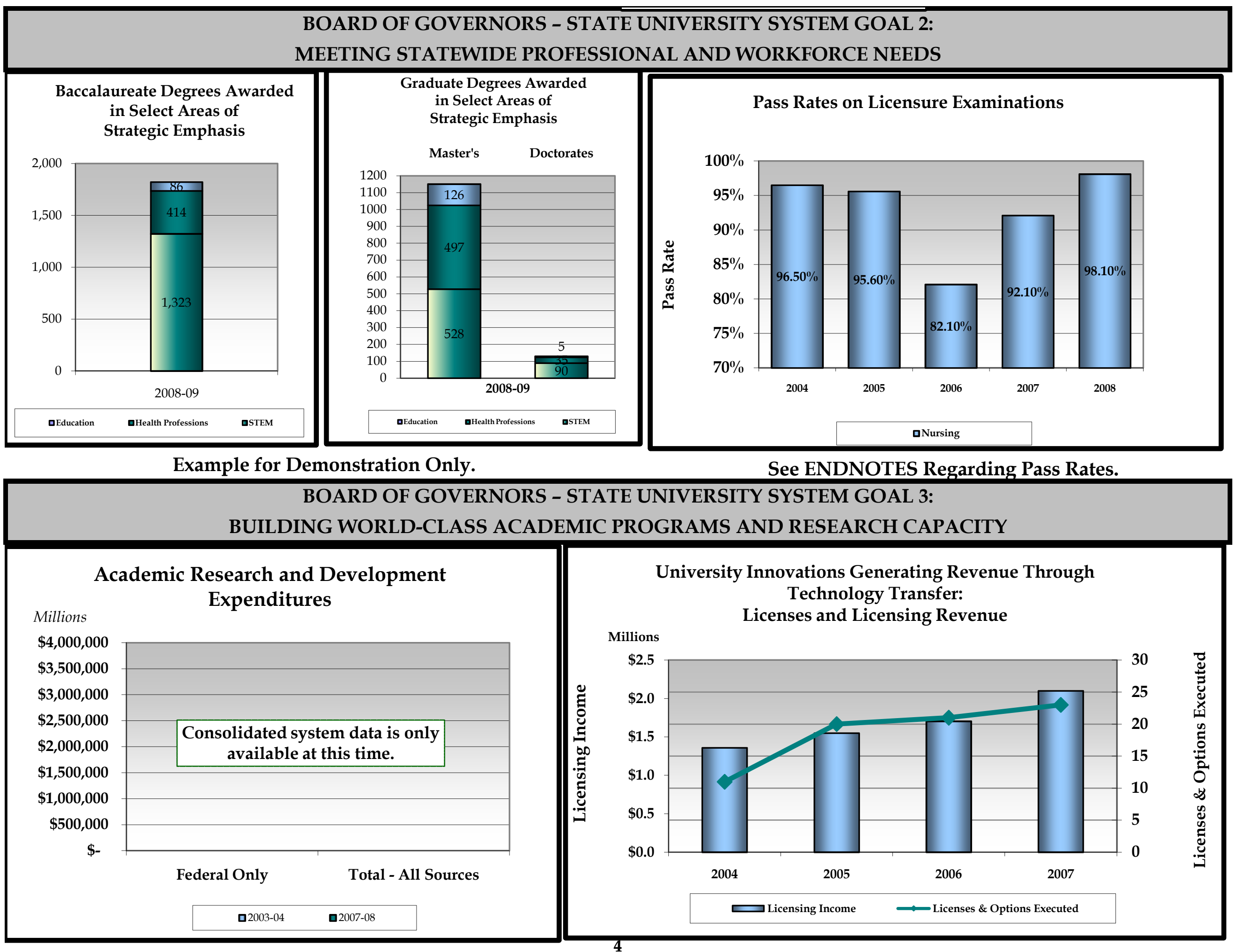


Key University Achievements [Include a maximum of three in each category.]

\section{- Student awards/achievements}

(1) Sixteen USF students were selected to participate in a gathering of the world's top college students at Education Without Borders 2009, a biennial international student conference held in Dubai, United Arab Emirates. They were part a delegation of 1,000 students representing 120 nations and 300 universities from around the world. Aki Nakanishi, a USF anthropology master's student, earned one of eight prizes awarded to student presenters at the conference.

(2) A team of USF students and their faculty advisor received a competitive Phase II Grant from the U.S. Environmental Protection Agency. The \$75,000 award was part of the EPA's prestigious People, Prosperity, and Planet (P3) Competition. The USF team was one of six selected nationally to receive the annual award.

(3) A group of USF mass communications students brought home USF's first Telly Award for its winning entry in the documentary category, beating out thousands of entries from established media outlets and businesses. The Telly Awards honor the very best local, regional, and cable television commercials and programs, as well as the finest video and film productions, and work created for the Web.

\section{Program awards/achievements}

Several USF graduate programs are ranked in the 2010 America's Best Graduate Schools edition of U.S. News \& World Report. Ranked programs are industrial \& organizational psychology (\#8), public health (\#20), criminology (\#22), audiology (\#24), rehabilitation counseling (\#39), speech-language pathology (\#46), library and information studies (\#29), education (\#54), clinical psychology (\#57), physical therapy (\#69), social work (\#71), nursing (\#72), psychology (\#74), and fine arts (\#81).

(2) The USF Army ROTC program received the MacArthur Award in recognition of the battalion's excellence in 2008. The USF Army ROTC battalion was one of only eight programs among 273 nationwide to earn the award, placing it in the top three percent of all U.S. Army ROTC programs nationally. (3) The Osher Lifelong Learning Institute at USF received a second \$1 million endowment grant in 2008 from the Bernard Osher Foundation in recognition of the Institute's efforts to promote lifelong learning opportunities for older adults in the Tampa area. The second endowment comes less than a year after the initial \$1 million endowment award in January 2008 and nearly four years after USF received its first Osher Foundation grant to establish the Osher Lifelong Learning Institute in 2005. The awards are based on demonstrated program success, university support and community participation. 


\section{Institutional awards/achievements}

(1) The USF Power Center for Utility Explorations and Progress Energy Florida have been selected by Florida's Energy and Climate Commission to build the largest and most comprehensive smart grid in the Southeast, serving at least 5,000 customers on the west side of St. Petersburg and St. Pete Beach.

(2) USF will become the nation's first university to partner with the Department of Veterans Affairs in a specialized effort to support returning troops who enroll in classes under the new GI Bill.

\section{- Faculty awards/achievements}

(1) Several members of the USF faculty have earned prestigious national and international awards in recognition of their research and instructional achievements. Faculty awards include Fulbright, Guggenheim, and Getty fellowships, and awards from the National Endowment for the Humanities and the National Science Foundation.

(2) USF Literature Professor Rogers was installed as a Corresponding Fellow of the British Academy in recognition of his outstanding achievements as a literary scholar. On a par with the National Academy of Sciences in the
Research awards/achievements

USF is home to the Florida Center of Excellence for Biomolecular Identification and Targeted Therapeutics (FCoE-BITT), a comprehensive center that enhances interactions between scientists and engineers to identify molecules of human health significance and develop novel methods for use in diagnosis, prevention and treatment of human disease. FCoE-BITT encompasses the full range from discovery to commercialization and is expected to create an infrastructure that supports collaboration across several academic disciplines and various technology transfer resources.

(2) USF researchers have developed a wheelchair-mounted robotic arm (WMRA) that captures the user's brain waves and converts them into robotic movements. The revolutionary device can help people with disabilities better perform their activities of daily living.

(3) The National Science Foundation highlighted USF researcher Kathryn Borman's work investigating student pathways on the road to careers in the fields of science, technology, engineering and mathematics (STEM) at a special NSF program in Virginia. Her research draws on the wealth of data from the state of Florida about students in public postsecondary institutions to examine their progress from high school through college and into their later career placements in STEM or other fields.

(4) USF is launching on a bold new plan to fight diabetes on every front with its Center of Excellence for Diabetes and Autoimmune Disorders. Already a national leader in epidemiological research to understand and prevent diabetes, USF is working to dramatically increase its clinical research, expand its diabetes education program, and establish a comprehensive center that will offer patients a new level of care in Florida. USF hopes to build facilities to conduct research on possible cures for diabetes, in both outpatient and inpatient settings. USF's Pediatric Epidemiology Center has received more than $\$ 300$ million in federal grant funding to direct global efforts in juvenile diabetes research. 
[AVAILABLE FOR DISPLAY OF INSTITUTIONAL PERFORMANCE ON MEASURES RELATED TO

RESOURCES, EFFICIENCIES, AND EFFECTIVENESS

\section{Undergraduate Retention and Graduation Rates}

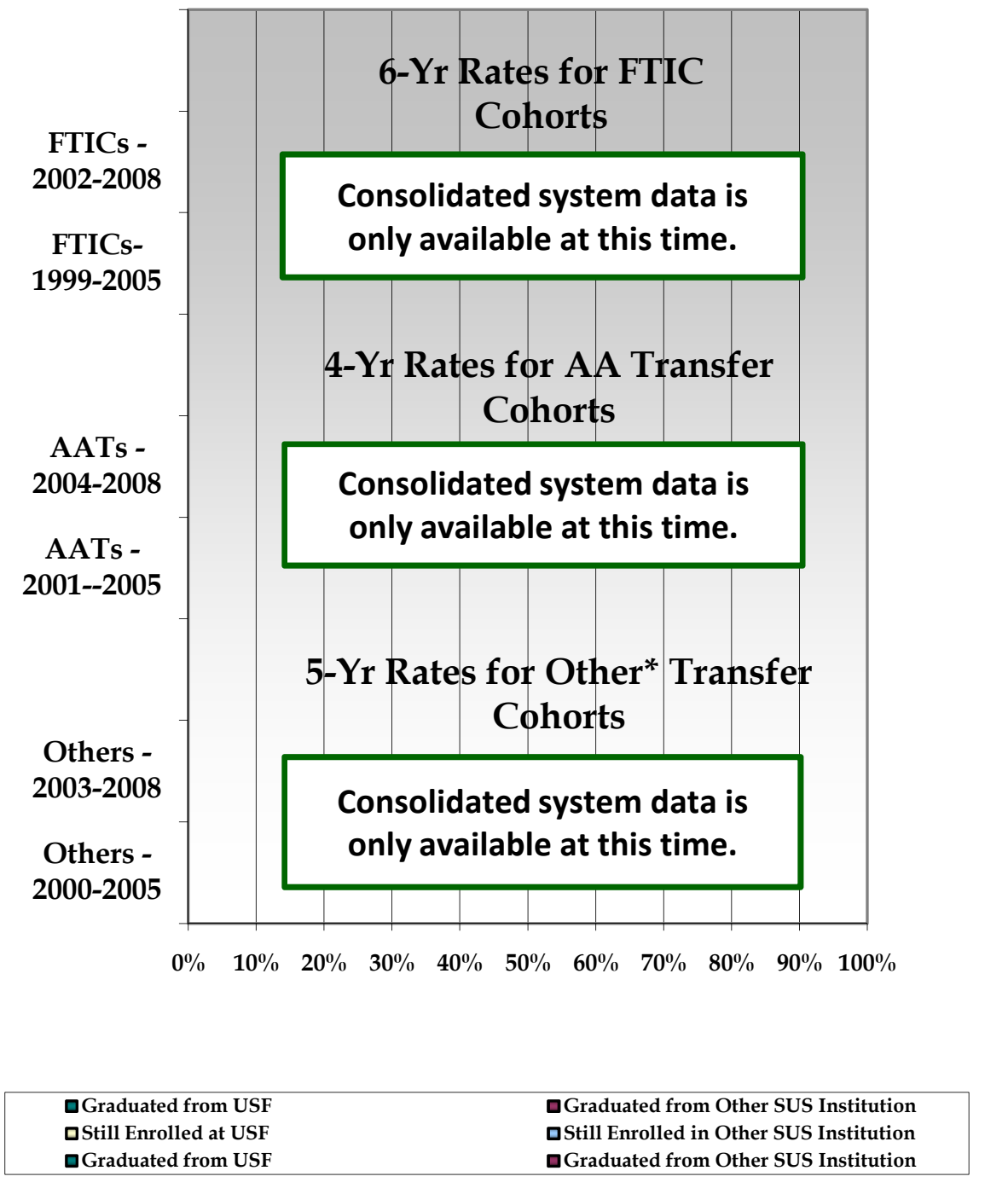

* The composition of "Other Transfer" cohorts may vary greatly by institution.

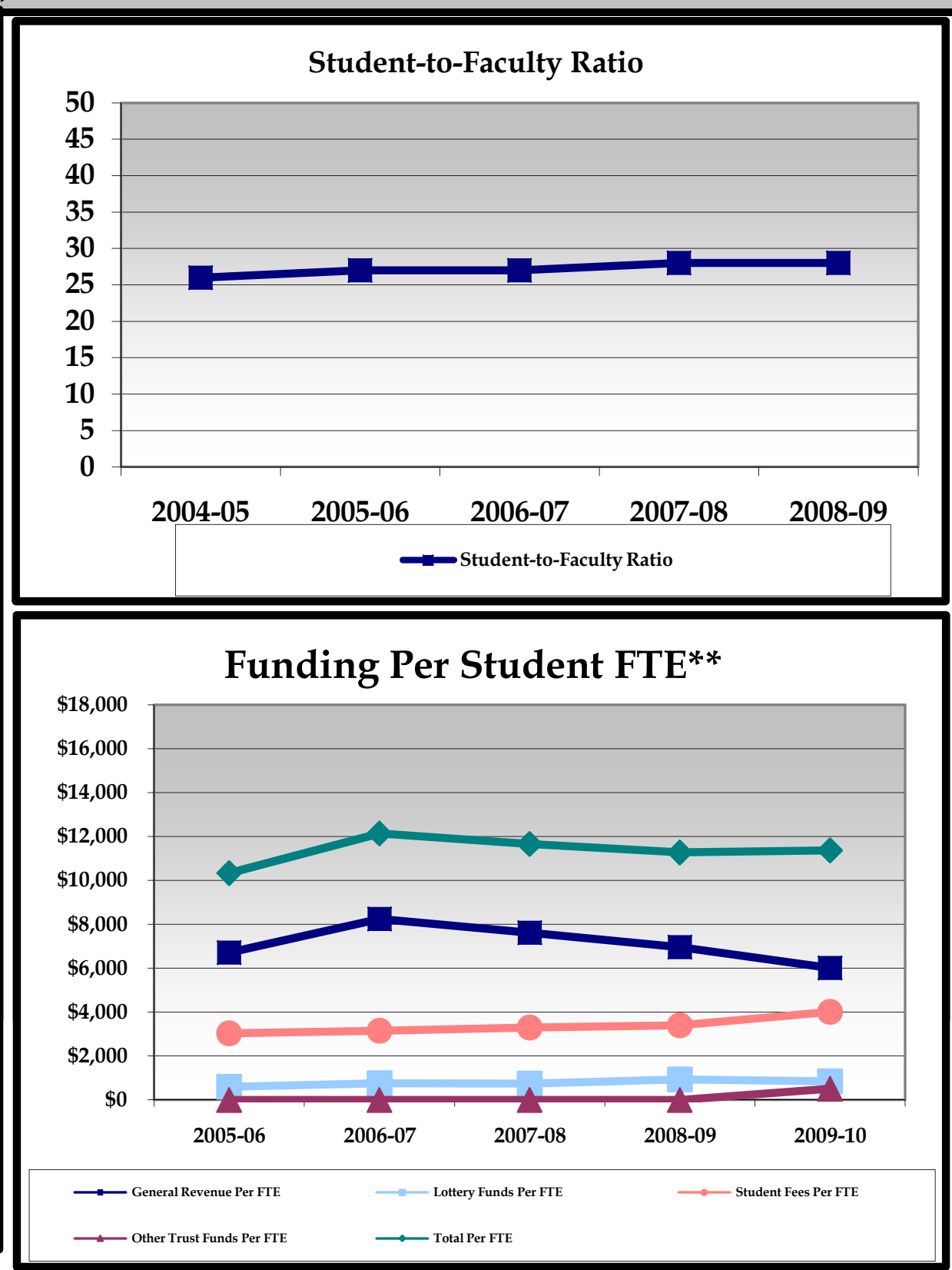

** FTE for this metric uses the standard IPEDS definition of FTE, equal to 30 credit hours for undergraduates and $\mathbf{2 4}$ for graduates. 


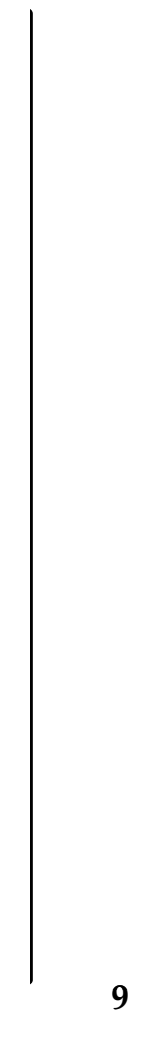




\section{$\underline{\text { Introduction }}$}

\section{- Mission}

As Florida's leading public metropolitan research university, USF is dedicated to excellence in student access and success, research and scientific discovery, and innovation and collaborations.

\section{USF 2007-2012 Strategic Plan:}

http://www.ods.usf.edu/Plans/Strategic/vision-mission.htm

\section{- Vision}

The University of South Florida envisions itself as a pre-eminent research university with state, national and global impact, and positioned for membership in the Association of American Universities (AAU).

USF 2007-2012 Strategic Plan:

http://www.ods.usf.edu/Plans/Strategic/vision-mission.htm

\section{- Other Contextual Introductory Comments}

USF consists of the main research campus in Tampa, which includes USF Health, USF Research Park, USF Downtown Center, and USF College of Marine Science in St. Petersburg.

\section{BOARD OF GOVERNORS - STATE UNIVERSITY SYSTEM GOAL 1: ACCESS TO AND PRODUCTION OF DEGREES}

USF is committed to access and the success of its students. Production of degrees is a culmination of student experiences, achievements, and success at the institution, and therefore becomes a measure of student success. As such, student success (i.e. enhanced preparedness, retention, persistence, graduation and placement rates) has been the primary goal of undergraduate and graduate education initiatives.

In 2008-09, USF awarded 8,730 degrees, of which more than 6,000 were bachelor's degrees, more than 2,000 were master's degrees, and nearly 300 were doctoral degrees.

At the undergraduate level, the university has made significant investments in programs and services to help students meet their fullest potential. By increasing the number of academic advisors, expanding tutoring services, encouraging undergraduate research, improving orientation, constructing new residence halls, and updating policies, USF is taking a comprehensive approach to improving the undergraduate experience in an effort to improve graduation rates and the overall collegiate experience.

In support of the university's strategic plan, graduate enrollment and diversity are on the rise - an indication of USF's intentions to strengthen its position as Florida's number two research university. Graduate studies and research are the hallmarks of the Tampa campus as a premier destination for world-class graduate students, postdoctoral fellows and faculty. Graduate and professional education at USF has been on a strong forward trajectory with exemplary educational and research opportunities for graduate students developed to promote our next state, national, and global leaders. 
GOAL 1: ACCESS TO AND PRODUCTION OF DEGREES (Continued)

Graduate level I hours (master's courses) have increased 3-4\% and Graduate level II (doctoral graduate hours) have increased $23 \%$. Diversity numbers are also strong, rising to $23 \%$ of all graduate students. The USF Graduate School is outperforming institutional goals for number of doctorates awarded, particularly in STEM areas, international student enrollment, and time to degree completion. Continuing this trend prepares the nation's next generation of leaders, thinkers and scientists by replenishing the ranks of the professoriate for American higher education.

Overall, more than one third of the USF student body is comprised of students who identify themselves as races/ethnicities that are nonWhite. USF's student diversity is a hallmark of the institution and has been recognized by leading publications over the past several years.

Located in the heart of Tampa, USF is located less than 10 minutes from downtown, where the institution also maintains a center for professional and workforce education. USF Health's presence permeates the Bay area through partnerships with hospitals and other health care organizations throughout Hillsborough County. The institution's broad geographic reach further supports its commitment to providing access to higher education.

\section{BOARD OF GOVERNORS - STATE UNIVERSITY SYSTEM GOAL 2: MEETING STATEWIDE PROFESSIONAL AND WORKFORCE NEEDS}

As a leading research university, USF offers a broad array of undergraduate and graduate degree programs preparing students to become leaders in business, industry, service, and research. Many degree programs align with state goals to meet professional and workforce needs, including education, health professions, the sciences, and emerging technologies.

Following the guidelines and selection of areas of strategic emphasis identified by the Board of Governors staff in consultation with business and industry groups, USF Tampa has experienced a positive growth trend in all identified areas (i.e., Education, Health Professions, STEM areas, Security \& Emergency Services, Globalization, and Regional Workforce Needs). From 2004 to 2008, USF Tampa has had a $45 \%$ increase in total degrees awarded combined for all areas of strategic emphasis.

\begin{tabular}{|c|c|c|c|c|c|}
\hline 5E Baccalaureate Đegrees: & Area & of:Ștrá & gाc Em & hasis: : & écific: \\
\hline $\begin{array}{l}\text { Awarded in Areas of stratege } \\
\quad \quad \text { Enpphasts }\end{array}$ & $\begin{array}{l}2004 \\
2005\end{array}$ & $\begin{array}{l}2005- \\
2006\end{array}$ & $\begin{array}{l}2006- \\
2007\end{array}$ & $\begin{array}{l}2007- \\
2008\end{array}$ & $\begin{array}{l}2008- \\
2009\end{array}$ \\
\hline Education & 79 & 78 & 74 & 83 & 86 \\
\hline Health Professions & 321 & 338 & 435 & 401 & 414 \\
\hline $\begin{array}{l}\text { Science, Technology, } \\
\text { Engineering, and Math }\end{array}$ & 993 & 1,050 & 1,199 & 1,246 & 1,323 \\
\hline Security \& Emergency Services & 261 & 242 & 295 & 318 & 325 \\
\hline Globalization & 327 & 338 & 370 & 401 & 432 \\
\hline Regional Workforce Needs & 760 & 759 & 836 & 889 & 971 \\
\hline $\begin{array}{c}\text { TOTAL: Areas of Strategic } \\
\text { Emphasis }\end{array}$ & 2,741 & 2,805 & 3,209 & 3,338 & 3,551 \\
\hline
\end{tabular}




\section{BOARD OF GOVERNORS - STATE UNIVERSITY SYSTEM GOAL 3: BUILDING WORLD-CLASS ACADEMIC PROGRAMS AND RESEARCH CAPACITY}

Research is a hallmark of every college, department and program at USF. It is an expectation and a privilege of every faculty member, whether it is sponsored by an external funding or carried out with support of university resources. As a result, there are scores of projects investigating basic research problems and tackling applied societal challenges that together all enhance our understanding of the world in the creation of new knowledge.

Research is a centerpiece of the university's strategic plan, is fundamental to the recruitment and retention of top faculty and gives a university distinction. Consistent with the USF Strategic Plan, the university has four internationally recognized research themes which span the entire campus: sustainability, integrated neurosciences, diabetes, and drug design, development and delivery.

USF's research enterprise is also remarkable on the national level. In fiscal year 2007, USF ranked $65^{\text {th }}$ of total research and development expenditures (external funding) for all universities and colleges and $44^{\text {th }}$ of all public institutions. USF also ranks $38^{\text {th }}$ in federal research expenditures for public universities and $62^{\text {nd }}$ for all universities. Last year, USF's funded research generated around \$360 million in external awards from federal, state, industry, foundation and other sponsors who are our partners in discovery and innovation that benefits Florida citizens, develops and commercializes products, knowhow and processes, and creates start-up companies and jobs. Such activities lead to economic development and create solutions to local, national and global problems.

Research firmly connects the university with the local Tampa Bay community through service, outreach and engagement activities, the corporate community through patenting and licensing of technology and targeted research, with other academics through collaborative and cooperative programs and globally through our relationships with research colleagues. Research also connects the system through multidisciplinary approaches to a common problem. Research provides opportunity to students and prepares them for success in their chosen fields or for graduate and professional education.

Of equal importance, research and scholarship in the humanities and arts improve the quality of life for our citizens and elevate the reputation of USF through performances, works of art, published books and other writings, and public commentary. In support of the next generation of scholars, USF has established the Provost's Postdoctoral Scholars Initiative in Humanities and Social Sciences. This initiative will support five new postdoctoral scholars in these areas and establish a new Office of Postdoctoral Affairs in the Graduate School that will allow strategic planning and data collection related to all USF postdoctoral scholars. Overall, there has been an $86 \%$ increase in the number of postdoctoral scholars since 2003, with 231 postdoctorates reported for Fall 2008.

In 2008-09, three members of the USF faculty were identified as national academy members and eight received nationally prestigious faculty awards as defined by the Top American Research Universities (TARU). USF's commitment to applied research is evident by a 50 percent increase in the total number of patents issued since 2004 . 


\section{BOARD OF GOVERNORS - STATE UNIVERSITY SYSTEM GOAL 4: MEETING COMMUNITY NEEDS AND FULFILLING UNIQUE INSTITUTIONAL RESPONSIBILITIES}

The core of the USF system is a growing, energetic campus in the heart of Tampa. What was once known as local university serving commuter students, today USF is one of the nation's top research universities with a vibrant campus community and strong research focus.

With a 213\% increase between 2000-2007, no other American university grew its federal research enterprise at a faster rate than USF, according to the Chronicle of Higher Education's 2009-10 Almanac. This distinction is a clear example of USF's aspirations to become eligible for membership in the Association of American Universities (AAU), an organization of 62 leading public and private research universities in the U.S. and Canada (34 public, 26 private, 2 Canadian). A focus on meeting the stringent criteria for AAU invitation-only membership represents the highest level in which a university can benchmark its achievements.

USF's 2007-2012 Strategic Plan is a bold, ambitious plan to elevate the performance and rankings of USF and provides the USF community with a clear vision, goals, strategies and measures to promote alignment and success. It is clearly directed at ensuring student success, contributing innovation and new knowledge and advancing economic development in Florida, the nation, and globally.

A unique example of the integration of the USF Strategic Plan into the university's operations is the way USF incorporates the budget planning process into the implementation of the strategic planning process. USF aligns its budget with institutional strategic priorities through effectively communicating and engaging all stakeholders in a transparent, focused, and disciplined manner with a mind to preserving excellence; containing costs; leveraging efficiencies; generating new revenue; and maximizing performance.
USF's focus on integrated, interdisciplinary inquiry, one of the four pillars of the university's strategic plan, is evident both in instructional and research programs. From new doctoral programs to undergraduate research, graduate school partnerships, and community outreach initiatives, USF is positioned as an emerging global leader in a new way of approaching learning and discovery.

USF Health is an enterprise dedicated to making life better by improving health in the wider environment, in communities, and for individuals. USF Health has, as its core, the three colleges of Public Health, Nursing and Medicine, including a School of Physical Therapy as well as the healthcare delivered by its clinicians. Originally founded as the USF Medical Center in 1965, its name has been changed to USF Health to reflect its collaborative focus on the full continuum of health.

Recently, the Florida Board of Governors granted USF approval to establish new doctoral programs in history, government, and sociology. The programs are linked, which is quite different from traditional, discipline-based programs. They focus on building sustainable healthy communities in a global context. These new programs join existing dual and interdisciplinary degree programs both at the undergraduate and graduate level.

In recognition of USF's service in the community, it was placed on the Corporation for National and Community Service's President's Higher Education Community Service Honor Roll for exemplary service efforts and service to America's communities. 


\section{Additional Information on Quality, Resources, Efficiencies, and}

\section{Effectiveness}

The $R / V$ WeatherBird II was purchased by USF for $\$ 2.1$ million for use through the Florida Institute of Oceanography, a consortium of

Florida's public universities, private higher education institutions and state agencies involved in marine research.

\section{Additional Resources}

[For example, university links should be included for the following]

- Carnegie Classification

- Basic: RU/VH: Research Universities (very high research activity)

- Community Engagement: Outreach \& Partnerships

- Undergraduate Instructional Program:

CompDoc/MedVet: Comprehensive doctoral with medical/veterinary

- Graduate Instructional Program: Bal/HGC: Balanced arts \& sciences/professions, high graduate coexistence

- Enrollment Profile: HU: High undergraduate

- Undergraduate Profile: MFT4/S/HTI: Medium full-time four-year, selective, higher transfer-in

- Size and Setting: L4/NR: Large four-year, primarily nonresidential

http:// www.carnegiefoundation.org/classifications/sub.asp?key=748\&s $\underline{\mathrm{ubkey}}=13889 \& \mathrm{start}=782$

Voluntary System of Accountability College Portrait of

Undergraduate Education

http://www.collegeportraits.org/FL/USF

- Common Data Set

http://www.ods.usf.edu/DSS/Resources/CDS.asp

- College Navigator

http://nces.ed.gov/collegenavigator $/ ? \mathrm{q}=$ South + Florida\&s $=F$ $\underline{\text { L\&id}=137351}$

- University Institutional Research Unit http://www.research.usf.edu/

- University Strategic Plan http://www.ods.usf.edu/plans/strategic/ 
University Data Sources

USF Planning, Performance and Accountability:

http://www.ods.usf.edu/Plans/PPA/matrix.htm

\section{USF e-Profiles:}

http://ods.usf.edu/DSS/Resources/eProfiles.asp

\section{USF InfoCenter:}

http://usfweb3.usf.edu/infocenter/?report_category=STU

\section{USF Performance Dashboard:}

http://www.ods.usf.edu/Plans/PPA/dashboard.htm

\section{USF Peers:}

http://www.ie.usf.edu/Peer/
Section 9 of Annual Report: Progress on Other Primary Institutional Goals and Metrics as Outlined in the University Work Plan

- The University has identified Marine Science and Coastal Technologies as an area of strategic focus. With an unparalleled concentration of coastal marine programs, Tampa Bay is the largest marine research community in the Southeastern United States and USF is uniquely positioned to serve as the intellectual hub for technological advances and workforce development within this important industry.

- The marine-related industries contributed more than $\$ 25$ billion of the gross economic product to the State of Florida in 2006. With a recent Mote combine the strengths of Florida's two largest marine science research entities to conduct research together that is critical for ocean resources and needs throughout the state and nation. Mote's Aquaculture Research Park will demonstrate the commercial viability of closed-loop, environmentally sustainable protein production. - SRI works closely with USF's College of Marine Science and employs over 67 people on its St. Petersburg campus. SRI received $\$ 20 \mathrm{M}$ in incentive funds from the State in 2008 to support research and innovation for the next five years. In its first two years, SRI plans to infuse the workforce in the Tampa Bay area by adding 30 new positions to its St. Petersburg location; with the goal of creating at least 100 new positions in Florida (St. Petersburg and Orlando) over the five year period. SRI's strategic plan is to accelerate research and development and commercialization of technologies related to ocean science, maritime industry and port security. SRI has partnered with USF's College of Marine Science on a number of proposals and provided funding for numerous on-going research projects.

- Draper Laboratory has invested more than \$ 2 million in the development of a bioengineering research \& development facility, housed in USF's Research Park. The facility currently employs five full-time staff, with open positions for six additional full-time employees. Current research proposals have been submitted with a value of over \$ 3 million, with over fifty-percent USF involvement. In addition, Draper has awarded two URAD projects to individual USF faculty. 
Section 9 of Annual Report: Progress on Other Primary Institutional Goals and Metrics as Outlined in the University Work Plan

(Continued)

- New Energy Solar is currently funding a \$600,000 research project in the University's Physics Department for the development of window-based photovoltaic panels.

- NanoCVD has entered into a \$150,000 research project with the USF's department of Electrical Engineering to develop a nanoscale wireless communications system.

- New Energy Solar, NanoCVD, and Draper Laboratory represent new partnerships formed within the past year. 


\section{Appendices}

\section{List of Tables}

1 - Budget

2 - Federal Stimulus Dollars (ARRA)

3 - Other Core Resources

4 - Enrollment and Funding

5 - Undergraduate Education Data

A. Baccalaureate Degree Programs Implemented or Terminated

B. First-Year Persistence Rates

C. Undergraduate Progression and Graduation Rates

D. Baccalaureate Degrees Awarded

E. Baccalaureate Degrees Awarded in Areas of Strategic Emphasis

F. Baccalaureate Degrees Awarded to Underrepresented Groups

G. Baccalaureate Completions Without Excess Credit Hours

H. Undergraduate Course Offerings

I. Faculty Teaching Undergraduates

J. Undergraduate Instructional Faculty Compensation

K. Student-Faculty Ratios

L. Licensure Examination Pass Rates (Undergraduate)

M. Tuition Differential

6 - Graduate Education Data

A. Graduate Degree Programs Implemented or Terminated

B. Graduate Degrees Awarded

C. Graduate Degrees Awarded in Areas of Strategic Emphasis

D. Licensure Examination Pass Rates (Graduate)

7 - Research and Economic Development Data

A. Research and Development Expenditures

B. Other Research and Economic Development Outcomes

C. Centers of Excellence

D. Commercialization Assistance Grants

8 - Voluntary Support of Higher Education

9 - Progress on Other Primary Institutional Goals and Metrics As Outlined in the University Work Plan 


\begin{tabular}{|c|c|c|c|c|c|}
\hline \multicolumn{6}{|c|}{1 - Budget (Non-Medical) } \\
\hline & 2005-06 Actual & 2006-07 Actual & 2007-08 Actual & 2008-09 Actual & $\begin{array}{l}2009-10 \\
\text { Estimates }\end{array}$ \\
\hline \multicolumn{6}{|l|}{ Education and General } \\
\hline \multicolumn{6}{|l|}{ E\&G Revenues } \\
\hline $\begin{array}{c}\text { State Funds (Recurring GR } \\
\text { \& Lottery) }\end{array}$ & $\$ 211,949,231$ & $\$ 235,905,307$ & $\$ 238,733,135$ & $\$ 218,374,574$ & $\$ 193,987,401$ \\
\hline $\begin{array}{c}\text { State Funds (Non- } \\
\text { Recurring GR \& Lottery) }\end{array}$ & $\$ 500,000$ & $\$ 28,560,000$ & $\$ 7,874,087$ & $\$ 13,358,066$ & $\$ 1,277,886$ \\
\hline $\begin{array}{c}\text { Tuition (Resident/Non- } \\
\text { Resident) }\end{array}$ & $\$ 85,559,683$ & $\$ 89,914,042$ & $\$ 93,427,618$ & $\$ 93,118,003$ & $\$ 106,583,861$ \\
\hline Tuition Differential (UG) & $\$ 0$ & $\$ 0$ & $\$ 0$ & $\$ 2,626,024$ & $\$ 7,932,318$ \\
\hline $\begin{array}{l}\text { Other (Include Revenues } \\
\text { from Misc. Fees \& Fines) }\end{array}$ & $\$ 2,583,941$ & $\$ 2,784,454$ & $\$ 3,848,306$ & $\$ 3,838,564$ & $\$ 3,671,913$ \\
\hline $\begin{array}{c}\text { Phosphate Research Trust } \\
\text { Fund }\end{array}$ & $\$ 6,984,905$ & $\$ 7,141,734$ & $\$ 7,268,856$ & $\$ 7,287,963$ & $\$ 7,303,188$ \\
\hline Federal Stimulus Funds & $\$ 0$ & $\$ 0$ & $\$ 0$ & $\$ 0$ & $\$ 15,145,042$ \\
\hline \multirow[t]{2}{*}{ TOTAL } & $\$ 307,577,760$ & $\$ 364,305,537$ & $\$ 351,152,002$ & $\$ 338,603,194$ & $\$ 335,901,609$ \\
\hline & 2005-06 Actual & 2006-07 Actual & 2007-08 Actual & 2008-09 Actual & $\begin{array}{c}2009-10 \\
\text { Estimates }\end{array}$ \\
\hline \multicolumn{6}{|l|}{ EEG Expenditures } \\
\hline Instruction/Research & $\$ 200,808,241$ & $\$ 217,514,787$ & $\$ 211,445,741$ & $\$ 195,633,873$ & $\$ 246,352,039$ \\
\hline $\begin{array}{c}\text { Institutes and Research } \\
\text { Centers }\end{array}$ & $\$ 1,190,822$ & $\$ 1,234,810$ & $\$ 1,193,341$ & $\$ 1,024,089$ & $\$ 974,911$ \\
\hline PO\&M & $\$ 28,708,860$ & $\$ 32,025,878$ & $\$ 33,466,687$ & $\$ 31,870,980$ & $\$ 32,467,726$ \\
\hline $\begin{array}{l}\text { Administration and } \\
\text { Support Services }\end{array}$ & $\$ 11,299,150$ & $\$ 15,399,086$ & $\$ 14,242,463$ & $\$ 20,795,141$ & $\$ 26,496,847$ \\
\hline Radio/TV & $\$ 897,435$ & $\$ 953,802$ & $\$ 861,952$ & $\$ 815,056$ & $\$ 925,727$ \\
\hline Library/Audio Visual & $\$ 11,269,984$ & $\$ 11,886,131$ & $\$ 12,096,969$ & $\$ 11,945,995$ & $\$ 11,894,778$ \\
\hline Museums and Galleries & $\$ 750,947$ & $\$ 764,217$ & $\$ 740,451$ & $\$ 729,951$ & $\$ 652,679$ \\
\hline Agricultural Extension & $\$ 0$ & $\$ 0$ & $\$ 0$ & $\$ 0$ & $\$ 0$ \\
\hline Allied Clinics & $\$ 0$ & $\$ 0$ & $\$ 0$ & $\$ 0$ & $\$ 0$ \\
\hline Student Services & $\$ 17,043,635$ & $\$ 11,861,623$ & $\$ 18,631,075$ & $\$ 17,967,815$ & $\$ 16,963,659$ \\
\hline Intercollegiate Athletics & $\$ 288,260$ & $\$ 771,412$ & $\$ 513,486$ & $\$ 352,411$ & $\$ 375,739$ \\
\hline TOTAL & $\$ 272,257,334$ & $\$ 292,411,746$ & $\$ 293,192,165$ & $\$ 281,135,309$ & $\$ 337,104,105$ \\
\hline
\end{tabular}




\begin{tabular}{|c|c|c|c|c|c|}
\hline & 05-06 Actual & 06-07 Actual & 07-08 Actual & 08-09 Actual & $\begin{array}{c}2009-10 \\
\text { Estimates }\end{array}$ \\
\hline Contracts and Grants & & & & & \\
\hline Revenues & \multirow{2}{*}{\multicolumn{5}{|c|}{$\begin{array}{l}\text { Contracts \& Grants data is a USF system-wide function and consolidated system } \\
\text { data is only available at this time. }\end{array}$}} \\
\hline Expenditures & & & & & \\
\hline \multicolumn{6}{|l|}{ Auxiliary Enterprises } \\
\hline Revenues & \multirow{2}{*}{\multicolumn{5}{|c|}{$\begin{array}{l}\text { Auxiliary Enterprise data is a USF system-wide function and consolidated system } \\
\text { data is only available at this time. }\end{array}$}} \\
\hline Expenditures & & & & & \\
\hline \multicolumn{6}{|l|}{ Local Funds } \\
\hline Revenues & \multirow{2}{*}{\multicolumn{5}{|c|}{$\begin{array}{l}\text { Local Funds data is a USF system-wide function and consolidated system data is } \\
\text { only available at this time. }\end{array}$}} \\
\hline Expenditures & & & & & \\
\hline
\end{tabular}

\begin{tabular}{|c|c|c|c|c|c|}
\hline TOTAL REVENUES & $\$ 307,577,760$ & $\$ 364,305,537$ & $\$ 351,152,002$ & $\$ 338,603,194$ & $\$ 335,901,609$ \\
\hline TOTAL EXPENDITURES & $\$ 272,257,334$ & $\$ 292,411,746$ & $\$ 293,192,165$ & $\$ 281,135,309$ & $\$ 337,104,105$ \\
\hline
\end{tabular}

\begin{tabular}{|l|c|}
\hline \multicolumn{2}{|c|}{ 2 - Federal Stimulus Dollars (ARRA) } \\
\hline & Proposed 2009-10 \\
\hline \# Jobs Saved/Created & USF (No HSC) \\
\hline Proposed Operating Budget Detail & 425 \\
\hline Jobs Saved/Created & $\$ 15,145,042$ \\
\hline Scholarships & 0 \\
\hline Library Resources & 0 \\
\hline Building Repairs/Alterations & 0 \\
\hline Motor Vehicles & 0 \\
\hline Printing & 0 \\
\hline Furniture \& Equipment & 0 \\
\hline Information Technology Equipment & 0 \\
\hline Financial Aid to Medical Students & 0 \\
\hline Other: & 0 \\
\hline TOTAL & $\$ 15,145,042$ \\
\hline
\end{tabular}




\begin{tabular}{|c|c|c|c|c|c|}
\hline \multicolumn{6}{|c|}{1 - Budget (Special Units-Health Science Center) } \\
\hline & 2005-06 Actual & 2006-07 Actual & 2007-08 Actual & 2008-09 Actual & $\begin{array}{c}2009-10 \\
\text { Estimates }\end{array}$ \\
\hline \multicolumn{6}{|l|}{ Health Science Center } \\
\hline \multicolumn{6}{|l|}{ HSC Revenues } \\
\hline $\begin{array}{c}\text { State Funds (Recurring GR } \\
\text { \& Lottery) }\end{array}$ & $\$ 54,904,671$ & $\$ 65,740,706$ & $\$ 65,814,423$ & $\$ 62,041,950$ & $\$ 61,541,893$ \\
\hline $\begin{array}{c}\text { State Funds (Non- } \\
\text { Recurring GR \& Lottery) }\end{array}$ & $\$ 577,179$ & $\$ 1,002,981$ & $\$ 929,801$ & $\$ 635,338$ & $\$ 0$ \\
\hline $\begin{array}{c}\text { Tuition (Resident/Non- } \\
\text { Resident) } \\
\end{array}$ & $\$ 16,542,838$ & $\$ 17,974,839$ & $\$ 22,648,230$ & $\$ 26,347,362$ & $\$ 25,022,280$ \\
\hline Tuition Differential (UG) & $\$ 0$ & $\$ 0$ & $\$ 0$ & $\$ 111,799$ & $\$ 225,072$ \\
\hline $\begin{array}{l}\text { Other (Include Revenues } \\
\text { from Misc. Fees \& Fines) }\end{array}$ & $\$ 0$ & $\$ 4,678,832$ & $\$ 0$ & $\$ 0$ & $\$ 0$ \\
\hline $\begin{array}{c}\text { Phosphate Research Trust } \\
\text { Fund } \\
\end{array}$ & $\$ 0$ & $\$ 0$ & $\$ 0$ & $\$ 0$ & $\$ 0$ \\
\hline Federal Stimulus Funds & $\$ 0$ & $\$ 0$ & $\$ 0$ & $\$ 0$ & $\$ 4,569,090$ \\
\hline \multirow[t]{2}{*}{ TOTAL } & $\$ 72,024,688$ & $\$ 89,397,358$ & $\$ 89,392,454$ & $\$ 89,136,449$ & $\$ 91,358,335$ \\
\hline & 2005-06 Actual & 2006-07 Actual & 2007-08 Actual & 2008-09 Actual & $\begin{array}{c}2009-10 \\
\text { Estimates }\end{array}$ \\
\hline \multicolumn{6}{|l|}{ HSC Expenditures } \\
\hline Instruction/Research & $\$ 54,709,055$ & $\$ 63,448,633$ & $\$ 64,625,114$ & $\$ 64,047,565$ & $\$ 82,218,441$ \\
\hline $\begin{array}{c}\text { Institutes and Research } \\
\text { Centers } \\
\end{array}$ & $\$ 306,730$ & $\$ 202,840$ & $\$ 154,396$ & $\$ 1,153$ & $\$ 0$ \\
\hline PO\&M & $\$ 26,661$ & $\$ 90,778$ & $\$ 64,095$ & $\$ 262,695$ & $\$ 225,167$ \\
\hline $\begin{array}{l}\text { Administration and } \\
\text { Support Services }\end{array}$ & $\$ 5,275,321$ & $\$ 4,797,748$ & $\$ 5,200,070$ & $\$ 4,463,186$ & $\$ 3,602,325$ \\
\hline Radio/TV & $\$ 0$ & $\$ 0$ & $\$ 0$ & $\$ 0$ & $\$ 0$ \\
\hline Library/Audio Visual & $\$ 3,001,641$ & $\$ 3,008,725$ & $\$ 2,903,725$ & $\$ 2,787,282$ & $\$ 2,535,669$ \\
\hline Museums and Galleries & $\$ 0$ & $\$ 0$ & $\$ 0$ & $\$ 0$ & $\$ 0$ \\
\hline Agricultural Extension & $\$ 0$ & $\$ 0$ & $\$ 0$ & $\$ 0$ & $\$ 0$ \\
\hline Allied Clinics & $\$ 0$ & $\$ 0$ & $\$ 0$ & $\$ 0$ & $\$ 0$ \\
\hline Student Services & $\$ 0$ & $\$ 0$ & $\$ 0$ & $\$ 0$ & $\$ 0$ \\
\hline Intercollegiate Athletics & $\$ 0$ & $\$ 0$ & $\$ 0$ & $\$ 0$ & $\$ 0$ \\
\hline TOTAL & $\$ 63,319,408$ & $\$ 71,548,724$ & $\$ 72,947,400$ & $\$ 71,561,881$ & $\$ 88,581,602$ \\
\hline
\end{tabular}




\begin{tabular}{|c|c|c|c|c|c|}
\hline & 05-06 Actual & 06-07 Actual & 07-08 Actual & 08-09 Actual & $2009-10$ \\
\hline \multicolumn{6}{|l|}{ Contracts and Grants } \\
\hline Revenues & $\$ 0$ & $\$ 0$ & $\$ 0$ & $\$ 0$ & $\$ 0$ \\
\hline Expenditures & $\$ 0$ & $\$ 0$ & $\$ 0$ & $\$ 0$ & $\$ 0$ \\
\hline \multicolumn{6}{|l|}{ Auxiliary Enterprises } \\
\hline Revenues & $\$ 0$ & $\$ 0$ & $\$ 0$ & $\$ 0$ & $\$ 0$ \\
\hline Expenditures & $\$ 0$ & $\$ 0$ & $\$ 0$ & $\$ 0$ & $\$ 0$ \\
\hline \multicolumn{6}{|l|}{ Local Funds } \\
\hline Revenues & $\$ 0$ & $\$ 0$ & $\$ 0$ & $\$ 0$ & $\$ 0$ \\
\hline Expenditures & $\$ 0$ & $\$ 0$ & $\$ 0$ & $\$ 0$ & $\$ 0$ \\
\hline \multicolumn{6}{|l|}{ Faculty Practice } \\
\hline \multicolumn{6}{|l|}{ Revenues } \\
\hline \multicolumn{6}{|l|}{ Expenditures } \\
\hline TOTAL REVENUES & $\$ 72,024,688$ & $\$ 89,397,358$ & $\$ 89,392,454$ & $\$ 89,136,449$ & $\$ 91,358,335$ \\
\hline TOTAL EXPENDITURES & $\$ 63,319,408$ & $\$ 71,548,724$ & $\$ 72,947,400$ & $\$ 71,561,881$ & $\$ 88,581,602$ \\
\hline \multicolumn{6}{|c|}{2 - Federal Stimulus Dollars (ARRA) } \\
\hline & & & & \multicolumn{2}{|c|}{ Proposed 2009-10 } \\
\hline & & & & \multicolumn{2}{|c|}{ USF-HSC } \\
\hline \# Jobs Saved/Created & & & & \multicolumn{2}{|c|}{54} \\
\hline \multicolumn{4}{|c|}{ Proposed Operating Budget Detail } & & \\
\hline \multicolumn{4}{|l|}{ Jobs Saved/Created } & \multicolumn{2}{|c|}{$\$ 4,569,090$} \\
\hline \multicolumn{4}{|l|}{ Scholarships } & \multicolumn{2}{|c|}{0} \\
\hline \multicolumn{4}{|l|}{ Library Resources } & \multicolumn{2}{|c|}{0} \\
\hline \multicolumn{4}{|c|}{ Building Repairs/Alterations } & \multicolumn{2}{|c|}{0} \\
\hline \multicolumn{4}{|l|}{ Motor Vehicles } & \multicolumn{2}{|c|}{0} \\
\hline \multicolumn{4}{|l|}{ Printing } & \multicolumn{2}{|c|}{0} \\
\hline \multicolumn{4}{|l|}{ Furniture \& Equipment } & \multicolumn{2}{|c|}{0} \\
\hline \multicolumn{4}{|c|}{ Information Technology Equipment } & \multicolumn{2}{|c|}{0} \\
\hline \multicolumn{4}{|c|}{ Financial Aid to Medical Students } & \multicolumn{2}{|c|}{0} \\
\hline \multicolumn{4}{|l|}{ Other: } & \multicolumn{2}{|c|}{0} \\
\hline TOTAL & & & & $\$ 4,5$ & 090 \\
\hline
\end{tabular}




\begin{tabular}{|c|c|c|c|c|c|}
\hline \multicolumn{7}{|c|}{3 - Other Core Resources (excludes Health Science Center) } \\
\hline $\begin{array}{c}\text { Funding per Student FTE } \\
\text { (US Definition) }\end{array}$ & $\mathbf{2 0 0 5 - 0 6}$ & $\mathbf{2 0 0 6 - 0 7}$ & $\mathbf{2 0 0 7 - 0 8}$ & $\mathbf{2 0 0 8 - 0 9}$ & $\mathbf{2 0 0 9 - 1 0}$ \\
\hline General Revenue per FTE & $\$ 6,712$ & $\$ 8,236$ & $\$ 7,617$ & $\$ 6,951$ & $\$ 6,014$ \\
\hline Lottery Funds per FTE & $\$ 592$ & $\$ 749$ & $\$ 742$ & $\$ 934$ & $\$ 836$ \\
\hline Other Trust Funds per FTE & $\$ 0$ & $\$ 0$ & $\$ 0$ & $\$ 0$ & $\$ 511$ \\
\hline Student Fees per FTE & $\$ 3,030$ & $\$ 3,149$ & $\$ 3,297$ & $\$ 3,388$ & $\$ 4,006$ \\
\hline Total per FTE Student & $\$ 10,334$ & $\$ 12,134$ & $\$ 11,656$ & $\$ 11,273$ & $\$ 11,366$ \\
\hline
\end{tabular}

** FTE for this metric uses the standard IPEDS definition of FTE, equal to 30 credit hours for undergraduates and 24 for graduates.

\begin{tabular}{|c|c|c|c|c|c|c|c|c|c|c|}
\hline \multirow{2}{*}{ Personnel Headcount } & \multicolumn{2}{|c|}{ Fall 2004} & \multicolumn{2}{|c|}{ Fall 2005} & \multicolumn{2}{|c|}{ Fall 2006} & \multicolumn{2}{|c|}{ Fall 2007} & \multicolumn{2}{|c|}{ Fall 2008} \\
\hline & FT & PT & FT & PT & FT & PT & FT & PT & FT & PT \\
\hline $\begin{array}{c}\text { Total Tenure/ Tenure-track } \\
\text { Faculty }\end{array}$ & 1,036 & 69 & 1,049 & 85 & 1,076 & 75 & 1,034 & 77 & 969 & 78 \\
\hline $\begin{array}{c}\text { Total Non-Tenure Track } \\
\text { Faculty }\end{array}$ & 392 & 145 & 434 & 149 & 480 & 147 & 519 & 153 & 419 & 132 \\
\hline $\begin{array}{c}\text { Total Graduate Assistants/ } \\
\text { Associates }\end{array}$ & & 1,577 & & 1,621 & & 1,692 & & 1,694 & & 1697 \\
\hline $\begin{array}{c}\text { Total Executive/ Ad- } \\
\text { ministrative/ Managerial }\end{array}$ & 435 & 9 & 443 & 12 & 463 & 16 & 517 & 15 & 527 & 15 \\
\hline Total Other Professional & 1,873 & 163 & 1,662 & 83 & 1,687 & 95 & 1,593 & 85 & 1587 & 70 \\
\hline Total Non-Professional & 1,554 & 42 & 1,508 & 29 & 1,538 & 31 & 1,618 & 41 & 1580 & 36 \\
\hline Space & Fall & 2004 & Fall & 2005 & Fall & 2006 & Fall & 2007 & Fall & 2008 \\
\hline $\begin{array}{c}\text { Space Utilization } \\
\text { Percentage (Classrooms) }\end{array}$ & 118 & $46 \%$ & 112. & $75 \%$ & 116 & $58 \%$ & 117. & $24 \%$ & 127. & $33 \%$ \\
\hline
\end{tabular}


4 - Enrollment and Funding

\begin{tabular}{|c|c|c|c|c|c|c|}
\hline $\begin{array}{l}\text { For entire } \\
\text { institution: } \\
\text { Annual FTE }\end{array}$ & $\begin{array}{l}\text { Funded } \\
2007-08\end{array}$ & $\begin{array}{c}2007-08 \\
\text { Actual }\end{array}$ & $\begin{array}{l}\text { Funded } \\
2008-09\end{array}$ & 2008-09 Actual & $\begin{array}{l}\text { Funded } \\
\text { 2009-10 }\end{array}$ & $\begin{array}{c}2009-10 \\
\text { Estimated }\end{array}$ \\
\hline $\begin{array}{c}\text { FL Resident } \\
\text { Lower }\end{array}$ & 8,720 & 8,530 & 8,783 & 8,231 & 8,783 & 8,202 \\
\hline $\begin{array}{c}\text { FL Resident } \\
\text { Upper }\end{array}$ & 10,583 & 10,380 & 10,117 & 10,680 & 10,117 & 10,729 \\
\hline $\begin{array}{l}\text { FL Resident } \\
\text { Grad I }\end{array}$ & 3,167 & 3,229 & 3,018 & 3,405 & 3,018 & 3,470 \\
\hline $\begin{array}{c}\text { FL Resident } \\
\text { Grad II }\end{array}$ & 855 & 876 & 854 & 854 & 854 & 906 \\
\hline $\begin{array}{l}\text { Total FL } \\
\text { Resident }\end{array}$ & 23,325 & 23,017 & 22,772 & 23,170 & 22,772 & 23,307 \\
\hline $\begin{array}{c}\text { Non-Res. } \\
\text { Lower }\end{array}$ & & 368 & & 316 & & 329 \\
\hline $\begin{array}{l}\text { Non-Res. } \\
\text { Upper }\end{array}$ & & 363 & & 366 & & 363 \\
\hline $\begin{array}{l}\text { Non-Res. Grad } \\
\text { I }\end{array}$ & & 361 & & 366 & & 378 \\
\hline $\begin{array}{c}\text { Non-Res. Grad } \\
\text { II }\end{array}$ & & 243 & & 232 & & 214 \\
\hline Total Non-Res. & 1,317 & 1,335 & 1,297 & 1,280 & 1,297 & 1,284 \\
\hline Total Lower & & 8,898 & & 8,546 & & 8,531 \\
\hline Total Upper & & 10,743 & & 11,046 & & 11,092 \\
\hline Total Grad I & & 3,591 & & 3,771 & & 3,848 \\
\hline Total Grad II & & 1,120 & & 1,087 & & 1,120 \\
\hline Total FTE & 24,642 & 24,352 & 24,069 & 24,450 & 24,069 & 24,591 \\
\hline $\begin{array}{c}\text { Total FTE - US } \\
\text { Definition* }\end{array}$ & 32,839 & 32,466 & 32,092 & 32,579 & 32,092 & 32,788 \\
\hline
\end{tabular}




\begin{tabular}{|c|c|c|c|c|c|c|}
\hline Annual FTE & $\begin{array}{l}\text { Funded } \\
2007-08\end{array}$ & $\begin{array}{c}\text { 2007-08 } \\
\text { Actual }\end{array}$ & $\begin{array}{l}\text { Funded } \\
2008-09\end{array}$ & $\begin{array}{l}2008-09 \\
\text { Actual }\end{array}$ & $\begin{array}{l}\text { Funded } \\
2009-10\end{array}$ & $\begin{array}{c}2009-10 \\
\text { Estimated }\end{array}$ \\
\hline $\begin{array}{c}\text { FL Resident } \\
\text { Medical } \\
\text { Headcount }\end{array}$ & 480 & 470 & 480 & 465 & 480 & 480 \\
\hline $\begin{array}{c}\text { Non-Res. } \\
\text { Medical } \\
\text { Headcount } \\
\end{array}$ & & 11 & & 17 & & 0 \\
\hline $\begin{array}{c}\text { Total Medical } \\
\text { Headcount }\end{array}$ & & 481 & & 482 & & 480 \\
\hline $\begin{array}{c}\text { FL Resident } \\
\text { Dentistry } \\
\text { Headcount }\end{array}$ & 0 & 0 & 0 & 0 & 0 & 0 \\
\hline $\begin{array}{c}\text { Non-Res. } \\
\text { Dentistry } \\
\text { Headcount } \\
\end{array}$ & & 0 & & 0 & & 0 \\
\hline $\begin{array}{c}\text { Total Dentistry } \\
\text { Headcount }\end{array}$ & & 0 & & 0 & & 0 \\
\hline $\begin{array}{l}\text { FL Resident } \\
\text { Veterinary } \\
\text { Medicine } \\
\text { Headcount }\end{array}$ & 0 & 0 & 0 & 0 & 0 & 0 \\
\hline $\begin{array}{c}\text { Non-Res. } \\
\text { Veterinary } \\
\text { Medicine } \\
\text { Headcount }\end{array}$ & & 0 & & 0 & & 0 \\
\hline $\begin{array}{c}\text { Total } \\
\text { Veterinary } \\
\text { Medicine } \\
\text { Headcount } \\
\end{array}$ & & 0 & & 0 & & 0 \\
\hline $\begin{array}{l}\text { Total Non-Res. } \\
\text { Med., Den., } \\
\text { Vet. Medicine } \\
\text { Headcount }\end{array}$ & 0 & 0 & 0 & 0 & 0 & 0 \\
\hline
\end{tabular}




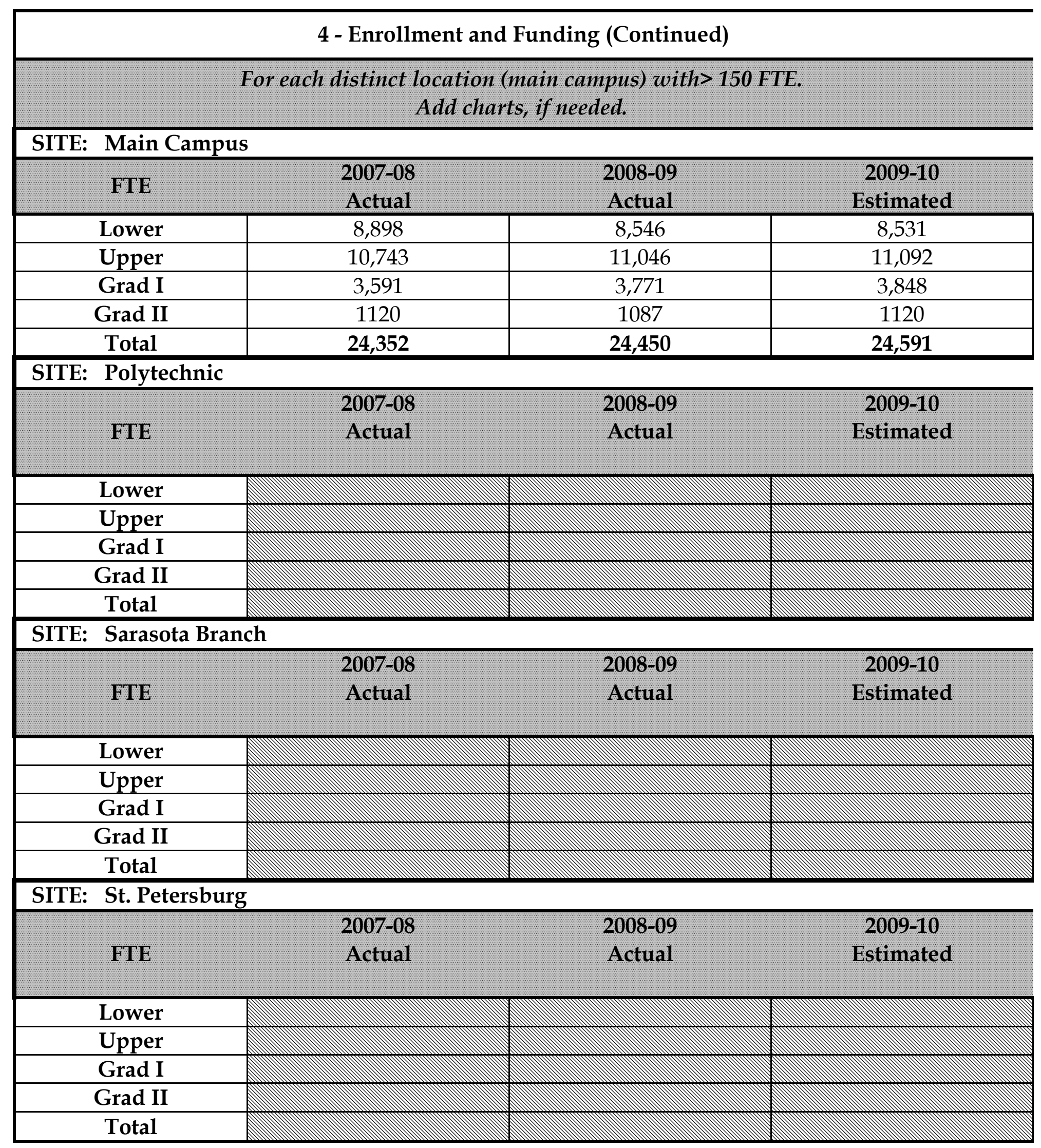




\begin{tabular}{|c|c|c|c|}
\hline \multicolumn{4}{|c|}{4 - Enrollment and Funding (Continued) } \\
\hline 011 & & & \\
\hline FTE & $\begin{array}{c}\text { 2007-08 } \\
\text { Actual }\end{array}$ & $\begin{array}{l}\text { 2008-09 } \\
\text { Actual }\end{array}$ & $\begin{array}{c}2009-10 \\
\text { Estimated }\end{array}$ \\
\hline Lower & $\overline{0}$ & $\overline{0}$ & 0 \\
\hline Upper & 0 & 0 & 0 \\
\hline Grad I & 481 & 482 & 480 \\
\hline Grad II & 0 & 0 & 0 \\
\hline Total & 481 & 482 & 480 \\
\hline FTE & $\begin{array}{c}2007-08 \\
\text { Actual }\end{array}$ & $\begin{array}{l}2008-09 \\
\text { Actual }\end{array}$ & $\begin{array}{c}2009-10 \\
\text { Estimated }\end{array}$ \\
\hline Lower & & & \\
\hline Upper & & & \\
\hline Grad I & & & \\
\hline Grad II & & & \\
\hline Total & & & \\
\hline
\end{tabular}




\begin{tabular}{|c|c|c|c|c|c|}
\hline \multicolumn{6}{|c|}{5 - Undergraduate Education Data } \\
\hline $\begin{array}{l}\text { 5A. Baccalaureate Degree Programs } \\
\text { Implemented or Terminated }\end{array}$ & $\begin{array}{c}\text { New } \\
\text { Program or } \\
\text { Termina- }\end{array}$ & $\begin{array}{l}\text { Date } \\
\text { Approved } \\
\text { by UBOT }\end{array}$ & $\begin{array}{c}\text { Date } \\
\text { Approved } \\
\text { by BOG, if }\end{array}$ & $\begin{array}{l}\text { Implementa- } \\
\text { tion Date, if } \\
\text { New }\end{array}$ & $\begin{array}{l}\text { Program CIP } \\
\text { Code }\end{array}$ \\
\hline Title and Program Level & tion? & & Needed & & \\
\hline General Studies & New & $6 / 12 / 2008$ & $\mathrm{n} / \mathrm{a}$ & Fall 2008 & 24.0102 \\
\hline Long Term Care Administration & New & $11 / 4 / 2008$ & $\mathrm{n} / \mathrm{a}$ & Fall 2008 & 51.0701 \\
\hline General Studies & New & $6 / 12 / 2008$ & $\mathrm{n} / \mathrm{a}$ & Fall 2008 & 24.0102 \\
\hline \multicolumn{6}{|c|}{ 5B. Successful First-Year Persistence Rates } \\
\hline YEAR OF SUS MATRICULATION & 2003 & 2004 & 2005 & 2006 & 2007 \\
\hline $\begin{array}{l}\text { Full-Time FTIC Cohort (Fall/Summer- } \\
\text { Fall) Size }\end{array}$ & 4,748 & 4,399 & 4,170 & 4,125 & 3,853 \\
\hline $\begin{array}{c}\text { Percentage Enrolled in Same IHE } \\
\text { After One Year }\end{array}$ & $83 \%$ & $83 \%$ & $82 \%$ & $83 \%$ & $86 \%$ \\
\hline \multicolumn{6}{|c|}{ 5C. Successful Undergraduate Progression and Graduation Rates } \\
\hline YEAR OF SUS MATRICULATION & 1999 & 2000 & 2001 & 2002 & 2003 \\
\hline FTIC Cohort (Fall/Summer-Fall) Size & $\mathrm{N} / \mathrm{A}$ & $\mathrm{N} / \mathrm{A}$ & $\mathrm{N} / \mathrm{A}$ & $\mathrm{N} / \mathrm{A}$ & $\mathrm{N} / \mathrm{A}$ \\
\hline $\begin{array}{c}\text { Percentage Graduated from Same IHE } \\
\text { Within } 4 \text { Years }\end{array}$ & $\mathrm{N} / \mathrm{A}$ & $\mathrm{N} / \mathrm{A}$ & $\mathrm{N} / \mathrm{A}$ & $\mathrm{N} / \mathrm{A}$ & $\mathrm{N} / \mathrm{A}$ \\
\hline $\begin{array}{l}\text { Percentage Graduated from Other } \\
\text { SUS IHE Within } 4 \text { Years }\end{array}$ & $\mathrm{N} / \mathrm{A}$ & $\mathrm{N} / \mathrm{A}$ & $\mathrm{N} / \mathrm{A}$ & $\mathrm{N} / \mathrm{A}$ & $\mathrm{N} / \mathrm{A}$ \\
\hline $\begin{array}{c}\text { Percentage Enrolled in Same IHE } \\
\text { After } 4 \text { Years }\end{array}$ & $\mathrm{N} / \mathrm{A}$ & $\mathrm{N} / \mathrm{A}$ & $\mathrm{N} / \mathrm{A}$ & $\mathrm{N} / \mathrm{A}$ & $\mathrm{N} / \mathrm{A}$ \\
\hline $\begin{array}{c}\text { Percentage Enrolled in Other SUS IHE } \\
\text { After } 4 \text { Years }\end{array}$ & $\mathrm{N} / \mathrm{A}$ & $\mathrm{N} / \mathrm{A}$ & $\mathrm{N} / \mathrm{A}$ & $\mathrm{N} / \mathrm{A}$ & $\mathrm{N} / \mathrm{A}$ \\
\hline $\begin{array}{l}\text { TOTAL 4-Year Success and Progress } \\
\text { Rate (Graduated or Enrolled in SUS) }\end{array}$ & $\mathrm{N} / \mathrm{A}$ & $\mathrm{N} / \mathrm{A}$ & $\mathrm{N} / \mathrm{A}$ & $\mathrm{N} / \mathrm{A}$ & $\mathrm{N} / \mathrm{A}$ \\
\hline $\begin{array}{c}\text { Percentage Graduated from Same IHE } \\
\text { Within } 6 \text { Years }\end{array}$ & $\mathrm{N} / \mathrm{A}$ & $\mathrm{N} / \mathrm{A}$ & $\mathrm{N} / \mathrm{A}$ & $\mathrm{N} / \mathrm{A}$ & $\mathrm{N} / \mathrm{A}$ \\
\hline $\begin{array}{l}\text { Percentage Graduated from Other } \\
\text { SUS IHE Within } 6 \text { Years }\end{array}$ & $\mathrm{N} / \mathrm{A}$ & $\mathrm{N} / \mathrm{A}$ & $\mathrm{N} / \mathrm{A}$ & $\mathrm{N} / \mathrm{A}$ & $\mathrm{N} / \mathrm{A}$ \\
\hline $\begin{array}{c}\text { Percentage Enrolled in Same IHE } \\
\text { After } 6 \text { Years }\end{array}$ & $\mathrm{N} / \mathrm{A}$ & $\mathrm{N} / \mathrm{A}$ & $\mathrm{N} / \mathrm{A}$ & $\mathrm{N} / \mathrm{A}$ & $\mathrm{N} / \mathrm{A}$ \\
\hline $\begin{array}{c}\text { Percentage Enrolled in Other SUS IHE } \\
\text { After } 6 \text { Years }\end{array}$ & $\mathrm{N} / \mathrm{A}$ & $\mathrm{N} / \mathrm{A}$ & $\mathrm{N} / \mathrm{A}$ & $\mathrm{N} / \mathrm{A}$ & $\mathrm{N} / \mathrm{A}$ \\
\hline $\begin{array}{l}\text { TOTAL 6-Year Success and Progress } \\
\text { Rate (Graduated or Enrolled in SUS) }\end{array}$ & $\mathrm{N} / \mathrm{A}$ & $\mathrm{N} / \mathrm{A}$ & $\mathrm{N} / \mathrm{A}$ & $\mathrm{N} / \mathrm{A}$ & $\mathrm{N} / \mathrm{A}$ \\
\hline
\end{tabular}




\begin{tabular}{|c|c|c|c|c|c|}
\hline YEAR OF SUS MATRICULATION & 2001 & 2002 & 2003 & 2004 & 2005 \\
\hline $\begin{array}{l}\text { AA Transfer Cohort (Fall/Summer- } \\
\text { Fall) Size }\end{array}$ & $\mathrm{N} / \mathrm{A}$ & $\mathrm{N} / \mathrm{A}$ & $\mathrm{N} / \mathrm{A}$ & $\mathrm{N} / \mathrm{A}$ & $\mathrm{N} / \mathrm{A}$ \\
\hline $\begin{array}{c}\text { Percentage Graduated from Same IHE } \\
\text { Within } 2 \text { Years }\end{array}$ & $\mathrm{N} / \mathrm{A}$ & $\mathrm{N} / \mathrm{A}$ & $\mathrm{N} / \mathrm{A}$ & $\mathrm{N} / \mathrm{A}$ & $\mathrm{N} / \mathrm{A}$ \\
\hline $\begin{array}{l}\text { Percentage Graduated from Other } \\
\text { SUS IHE Within } 2 \text { Years }\end{array}$ & $\mathrm{N} / \mathrm{A}$ & $\mathrm{N} / \mathrm{A}$ & $\mathrm{N} / \mathrm{A}$ & $\mathrm{N} / \mathrm{A}$ & $\mathrm{N} / \mathrm{A}$ \\
\hline $\begin{array}{c}\text { Percentage Enrolled in Same IHE } \\
\text { After } 2 \text { Years }\end{array}$ & $\mathrm{N} / \mathrm{A}$ & $\mathrm{N} / \mathrm{A}$ & $\mathrm{N} / \mathrm{A}$ & $\mathrm{N} / \mathrm{A}$ & $\mathrm{N} / \mathrm{A}$ \\
\hline $\begin{array}{c}\text { Percentage Enrolled in Other SUS IHE } \\
\text { After } 2 \text { Years }\end{array}$ & $\mathrm{N} / \mathrm{A}$ & $\mathrm{N} / \mathrm{A}$ & $\mathrm{N} / \mathrm{A}$ & $\mathrm{N} / \mathrm{A}$ & $\mathrm{N} / \mathrm{A}$ \\
\hline $\begin{array}{l}\text { TOTAL 2-Year Success and Progress } \\
\text { Rate (Graduated or Enrolled in SUS) }\end{array}$ & $\mathrm{N} / \mathrm{A}$ & $\mathrm{N} / \mathrm{A}$ & $\mathrm{N} / \mathrm{A}$ & $\mathrm{N} / \mathrm{A}$ & $\mathrm{N} / \mathrm{A}$ \\
\hline $\begin{array}{c}\text { Percentage Graduated from Same IHE } \\
\text { Within } 4 \text { Years }\end{array}$ & $\mathrm{N} / \mathrm{A}$ & $\mathrm{N} / \mathrm{A}$ & $\mathrm{N} / \mathrm{A}$ & $\mathrm{N} / \mathrm{A}$ & $\mathrm{N} / \mathrm{A}$ \\
\hline $\begin{array}{l}\text { Percentage Graduated from Other } \\
\text { SUS IHE Within } 4 \text { Years }\end{array}$ & $\mathrm{N} / \mathrm{A}$ & $\mathrm{N} / \mathrm{A}$ & $\mathrm{N} / \mathrm{A}$ & $\mathrm{N} / \mathrm{A}$ & $\mathrm{N} / \mathrm{A}$ \\
\hline $\begin{array}{c}\text { Percentage Enrolled in Same IHE } \\
\text { After } 4 \text { Years }\end{array}$ & $\mathrm{N} / \mathrm{A}$ & $\mathrm{N} / \mathrm{A}$ & $\mathrm{N} / \mathrm{A}$ & $\mathrm{N} / \mathrm{A}$ & $\mathrm{N} / \mathrm{A}$ \\
\hline $\begin{array}{c}\text { Percentage Enrolled in Other SUS IHE } \\
\text { After } 4 \text { Years }\end{array}$ & $\mathrm{N} / \mathrm{A}$ & $\mathrm{N} / \mathrm{A}$ & $\mathrm{N} / \mathrm{A}$ & $\mathrm{N} / \mathrm{A}$ & $\mathrm{N} / \mathrm{A}$ \\
\hline $\begin{array}{l}\text { TOTAL 4-Year Success and Progress } \\
\text { Rate (Graduated or Enrolled in SUS) }\end{array}$ & $\mathrm{N} / \mathrm{A}$ & $\mathrm{N} / \mathrm{A}$ & $\mathrm{N} / \mathrm{A}$ & $\mathrm{N} / \mathrm{A}$ & $\mathrm{N} / \mathrm{A}$ \\
\hline YEAR OF SUS MATRIC. & 2000 & 2001 & 2002 & 2003 & 2004 \\
\hline $\begin{array}{c}\text { Other Transfer Cohort (Fall/Summer- } \\
\text { Fall) Size }\end{array}$ & $\mathrm{N} / \mathrm{A}$ & $\mathrm{N} / \mathrm{A}$ & $\mathrm{N} / \mathrm{A}$ & $\mathrm{N} / \mathrm{A}$ & $\mathrm{N} / \mathrm{A}$ \\
\hline $\begin{array}{c}\text { Percentage Graduated from Same IHE } \\
\text { Within } 5 \text { Years }\end{array}$ & $\mathrm{N} / \mathrm{A}$ & $\mathrm{N} / \mathrm{A}$ & $\mathrm{N} / \mathrm{A}$ & $\mathrm{N} / \mathrm{A}$ & $\mathrm{N} / \mathrm{A}$ \\
\hline $\begin{array}{l}\text { Percentage Graduated from Other } \\
\text { SUS IHE Within } 5 \text { Years }\end{array}$ & $\mathrm{N} / \mathrm{A}$ & $\mathrm{N} / \mathrm{A}$ & $\mathrm{N} / \mathrm{A}$ & $\mathrm{N} / \mathrm{A}$ & $\mathrm{N} / \mathrm{A}$ \\
\hline $\begin{array}{c}\text { Percentage Enrolled in Same IHE } \\
\text { After } 5 \text { Years }\end{array}$ & $\mathrm{N} / \mathrm{A}$ & $\mathrm{N} / \mathrm{A}$ & $\mathrm{N} / \mathrm{A}$ & $\mathrm{N} / \mathrm{A}$ & $\mathrm{N} / \mathrm{A}$ \\
\hline $\begin{array}{c}\text { Percentage Enrolled in Other SUS IHE } \\
\text { After } 5 \text { Years }\end{array}$ & $\mathrm{N} / \mathrm{A}$ & $\mathrm{N} / \mathrm{A}$ & $\mathrm{N} / \mathrm{A}$ & $\mathrm{N} / \mathrm{A}$ & $\mathrm{N} / \mathrm{A}$ \\
\hline $\begin{array}{l}\text { TOTAL 5-Year Success and Progress } \\
\text { Rate (Graduated or Enrolled in SUS) }\end{array}$ & $\mathrm{N} / \mathrm{A}$ & $\mathrm{N} / \mathrm{A}$ & $\mathrm{N} / \mathrm{A}$ & $\mathrm{N} / \mathrm{A}$ & $\mathrm{N} / \mathrm{A}$ \\
\hline
\end{tabular}




\begin{tabular}{|c|c|c|c|c|c|}
\hline 5D. Baccalaureate Degrees Awarded & 2004-2005 & 2005-2006 & 2006-2007 & $2007-2008$ & 2008-2009 \\
\hline Baccalaureate Degrees & 4,633 & 4,926 & 5,479 & 5,758 & 6,059 \\
\hline 5E. Baccalaureate Degrees Awarded & \multicolumn{5}{|c|}{$\begin{array}{l}\text { Areas of Strategic Emphasis: Specific degree programs will be } \\
\text { identified for each university. [UNDUPLICATED COUNT] }\end{array}$} \\
\hline & 2004-2005 & 2005-2006 & 2006-2007 & $2007-2008$ & 2008-2009 \\
\hline Education & 79 & 78 & 74 & 83 & 86 \\
\hline Health Professions & 321 & 338 & 435 & 401 & 414 \\
\hline $\begin{array}{c}\text { Science, Technology, Engineering, } \\
\text { and Math }\end{array}$ & 993 & 1,050 & 1,199 & 1,246 & 1,323 \\
\hline Security \& Emergency Services & 261 & 242 & 295 & 318 & 325 \\
\hline Globalization & 327 & 338 & 370 & 401 & 432 \\
\hline Regional Workforce Needs & 760 & 759 & 836 & 889 & 971 \\
\hline TOTAL: Areas of Strategic Emphasis & 2,741 & 2,805 & 3,209 & 3,338 & 3,551 \\
\hline $\begin{array}{l}\text { 5F. Baccalaureate Degrees Awarded to } \\
\text { Underrepresented Groups }\end{array}$ & 2004-2005 & 2005-2006 & 2006-2007 & $2007-2008$ & 2008-2009 \\
\hline $\begin{array}{l}\text { \# of Baccalaureate Degrees Awarded } \\
\text { to Black Non-Hispanic Students }\end{array}$ & 518 & 613 & 686 & 723 & 786 \\
\hline $\begin{array}{c}\text { \% of Total Baccalaureate Degrees } \\
\text { (Excluding Those Awarded to Non- } \\
\text { Resident Aliens and Unreported) } \\
\text { Awarded to Black Non-Hispanic } \\
\text { Students }\end{array}$ & $11.2 \%$ & $13.1 \%$ & $13.1 \%$ & $13.2 \%$ & $13.5 \%$ \\
\hline $\begin{array}{c}\text { \# of Baccalaureate Degrees Awarded } \\
\text { to Hispanic Students }\end{array}$ & 481 & 511 & 620 & 657 & 759 \\
\hline $\begin{array}{l}\text { \% of Total Baccalaureate Degrees } \\
\text { (Excluding Those Awarded to Non- } \\
\text { Resident Aliens and Unreported) } \\
\text { Awarded to Hispanic Students }\end{array}$ & $10.6 \%$ & $10.9 \%$ & $11.8 \%$ & $12.0 \%$ & $13.00 \%$ \\
\hline $\begin{array}{c}\text { Number of Baccalaureate Degrees } \\
\text { Awarded to PELL Recipients (Defined } \\
\text { as Those Receiving PELL Within } 6 \\
\text { Years of Graduation) }\end{array}$ & 1,843 & 2,003 & 2,083 & 2,193 & 2260 \\
\hline $\begin{array}{l}\% \text { of Total Baccalaureate Degrees } \\
\text { (Excluding Those Awarded to Non- } \\
\text { Resident Aliens) Awarded to PELL } \\
\text { Recipients (Defined as Those } \\
\text { Receiving PELL Within } 6 \text { Years of } \\
\text { Graduation) }\end{array}$ & $40.6 \%$ & $42.9 \%$ & $39.6 \%$ & $40.0 \%$ & $38.80 \%$ \\
\hline
\end{tabular}




\begin{tabular}{|c|c|c|c|c|c|}
\hline $\begin{array}{l}\text { 5G. Baccalaureate Completion } \\
\text { Without Excess Credit Hours }\end{array}$ & 2004-2005 & 2005-2006 & 2006-2007 & $2007-2008$ & 2008-2009 \\
\hline $\begin{array}{c}\% \text { of Total Baccalaureate Degrees } \\
\text { Awarded Within } 110 \% \text { of Hours } \\
\text { Required for Degree }\end{array}$ & $\mathrm{N} / \mathrm{A}$ & $\mathrm{N} / \mathrm{A}$ & $\mathrm{N} / \mathrm{A}$ & $34.40 \%$ & $35.51 \%$ \\
\hline 5H. Undergraduate Course Offerings & Fall 2004 & Fall 2005 & Fall 2006 & Fall 2007 & Fall 2008 \\
\hline $\begin{array}{l}\text { Number of Undergraduate Course } \\
\text { Sections }\end{array}$ & 2,247 & 2,399 & 2,443 & 2,597 & 2,453 \\
\hline $\begin{array}{c}\% \text { of Undergraduate Course Sections } \\
\text { With }<30 \text { Students }\end{array}$ & $53.1 \%$ & $53.6 \%$ & $55.1 \%$ & $58.1 \%$ & $55.2 \%$ \\
\hline $\begin{array}{l}\% \text { of Undergraduate Course Sections } \\
\text { With }>=30 \text { and }<50 \text { Students }\end{array}$ & $25.7 \%$ & $28.8 \%$ & $28.5 \%$ & $26.3 \%$ & $27.7 \%$ \\
\hline $\begin{array}{l}\% \text { of Undergraduate Course Sections } \\
\text { With }>=50 \text { and }<100 \text { Students }\end{array}$ & $15.5 \%$ & $13.2 \%$ & $12.2 \%$ & $11.6 \%$ & $13.2 \%$ \\
\hline $\begin{array}{c}\% \text { of Undergraduate Course Sections } \\
\text { With }>=100 \text { Students }\end{array}$ & $5.7 \%$ & $4.4 \%$ & $4.2 \%$ & $4.0 \%$ & $3.9 \%$ \\
\hline 5I. Faculty Teaching Undergraduates & 2004-2005 & 2005-2006 & 2006-2007 & 2007-2008 & 2008-2009 \\
\hline $\begin{array}{c}\text { Percentage of Credit Hours Taught by } \\
\text { Faculty }\end{array}$ & $59.3 \%$ & $61.7 \%$ & $61.3 \%$ & $61.1 \%$ & $63.1 \%$ \\
\hline $\begin{array}{c}\text { Percentage of Credit Hours Taught by } \\
\text { Adjunct Faculty }\end{array}$ & $22.0 \%$ & $22.7 \%$ & $21.6 \%$ & $21.6 \%$ & $19.8 \%$ \\
\hline $\begin{array}{l}\text { Percentage of Credit Hours Taught by } \\
\text { Graduate Students }\end{array}$ & $18.5 \%$ & $15.2 \%$ & $16.6 \%$ & $16.9 \%$ & $16.5 \%$ \\
\hline $\begin{array}{l}\text { Percentage of Credit Hours Taught by } \\
\text { Other Instructors }\end{array}$ & $0.2 \%$ & $0.4 \%$ & $0.5 \%$ & $0.4 \%$ & $60.0 \%$ \\
\hline $\begin{array}{l}\text { 5J. Undergraduate Instructional } \\
\text { Faculty Compensation }\end{array}$ & Fall 2004 & Fall 2005 & Fall 2006 & Fall 2007 & Fall 2008 \\
\hline $\begin{array}{c}\text { Average Salary and Benefits for } \\
\text { Faculty Who Teach at Least One } \\
\text { Undergraduate Course }\end{array}$ & $\$ 79,100$ & $\$ 80,414$ & $\$ 82,840$ & $\$ 86,795$ & $\$ 89,571$ \\
\hline 5K. Student/Faculty Ratio & 2004-2005 & 2005-2006 & $2006-2007$ & $2007-2008$ & 2008-2009 \\
\hline $\begin{array}{l}\text { IPEDS/Common Data Set Student-to- } \\
\text { Faculty Ratio }\end{array}$ & 26 & 27 & 27 & 28 & 28 \\
\hline 5L. Licensure Pass Rates & 2004 & 2005 & 2006 & 2007 & 2008 \\
\hline $\begin{array}{l}\text { Nursing: Number of NCLEX First- } \\
\text { Time Test Takers - Baccalaureate }\end{array}$ & 112 & 121 & 95 & 152 & 157 \\
\hline $\begin{array}{l}\text { Nursing: Pass Rate for NCLEX First- } \\
\text { Time Test Takers - Baccalaureate }\end{array}$ & $95.5 \%$ & $95.6 \%$ & $82.1 \%$ & $92.1 \%$ & $98.1 \%$ \\
\hline \multicolumn{6}{|c|}{$\begin{array}{l}\text { Indicators for pass rates on other licensure exams will be added as data become available. [See } \\
\text { ENDNOTES.] }\end{array}$} \\
\hline
\end{tabular}




\begin{tabular}{|c|c|c|}
\hline 5M. Tuition Differential & 2008-2009 & $\begin{array}{l}\text { Sum-Fall } \\
2009\end{array}$ \\
\hline \multicolumn{3}{|l|}{ Revenues } \\
\hline Total Revenues Generated By the Tuition Differential & -- & -- \\
\hline \multicolumn{3}{|l|}{ Waivers } \\
\hline Number of Students Eligible for Waiver Based on FSAG Eligibility & 0 & 0 \\
\hline Number of Students Receiving a Waiver Based on FSAG Eligibility & 0 & 0 \\
\hline Value of Waivers Provided Based on FSAG Eligibility & 0 & 0 \\
\hline \multicolumn{3}{|c|}{$\begin{array}{l}\text { Report on the success of the tuition differential in achieving the articulated purpose. Include an update on } \\
\text { any performance measures that were specified in the BOG-approved tuition differential proposal. [NOTE: } \\
\text { In 2009, universities will only be able to report progress for the fall term and reiterate how the university } \\
\text { will monitor the long-term success of the tuition differential.] }\end{array}$} \\
\hline \multirow{2}{*}{\multicolumn{3}{|c|}{$\begin{array}{l}\text { Since differential tuition was first implemented in Fall of } 2008 \text { there are limited measurable outcomes. } \\
\text { However, USF has already: } \\
\text { - Expanded the number of academic advisors by } 8 \text { resulting in an increase in the first-year retention rate by } \\
6 \% \text { over the past two years. } \\
\text { - Reduced the student to advisor ratio to approximately } 420: 1 \text {; the goal over the next two years is to reduce } \\
\text { this to 330:1. } \\
\text { - A student tracking system has been implemented to guide more students through the degree process. } \\
\text { - Implemented a revised class schedule (Fall 2008) to improve classroom utilization and to reduce course } \\
\text { conflicts making it possible for more students to stay on track towards their degrees, and schedule their } \\
\text { courses in a more efficient manner. } \\
\text { Enhanced tutoring and learning services by combining decentralized resources from across campus. This } \\
\text { includes tutoring in most lower-level courses and the development of a writing center. This has helped to } \\
\text { reduce class failures, repeats, and students on probation and dismissal. Over the past two years the probation } \\
\text { rate of first-year students has decreased from an average of } 15 \% \text { after their first semester to less than } 12 \% \text {. }\end{array}$}} \\
\hline & & \\
\hline \multicolumn{3}{|c|}{$\begin{array}{l}\text { Detailed expenditures of the revenues generated by the tuition differential will be captured in the Operating } \\
\text { Budget submission each August. }\end{array}$} \\
\hline
\end{tabular}


6 - Graduate Education Data

\begin{tabular}{|c|c|c|c|c|c|}
\hline $\begin{array}{l}\text { 6A. GraduateDegree Programs } \\
\text { Implemented or Terminated }\end{array}$ & \multirow{2}{*}{$\begin{array}{c}\text { New Program } \\
\text { or Termina- } \\
\text { tion? }\end{array}$} & \multirow[b]{2}{*}{$\begin{array}{c}\text { Date Approved } \\
\text { by UBOT }\end{array}$} & \multirow{2}{*}{$\begin{array}{c}\text { Date } \\
\text { Approved by } \\
\text { BOG, if } \\
\text { Needed }\end{array}$} & \multirow{2}{*}{$\begin{array}{l}\text { Implementa- } \\
\text { tion Date, if } \\
\text { New }\end{array}$} & \multirow{2}{*}{$\begin{array}{l}\text { Program } \\
\text { CIP Code }\end{array}$} \\
\hline Title and Program Level & & & & & \\
\hline Urban/Regional Planning - M & New & $5 / 31 / 2007$ & $\mathrm{n} / \mathrm{a}$ & Fall 2008 & 4.0301 \\
\hline Marketing -M & New & $5 / 31 / 2007$ & $\mathrm{n} / \mathrm{a}$ & Fall 2008 & 52.1401 \\
\hline Creative Writing - M & New & $9 / 6 / 2007$ & $\mathrm{n} / \mathrm{a}$ & Fall 2008 & 23.0501 \\
\hline Urban/Community Design - M & New & $1 / 24 / 2008$ & $\mathrm{n} / \mathrm{a}$ & Fall 2009 & 4.0401 \\
\hline Real Estate - M & New & $1 / 24 / 2008$ & $\mathrm{n} / \mathrm{a}$ & Fall 2009 & 52.1501 \\
\hline Materials Science/Engineering - M & New & $11 / 29 / 2007$ & $\mathrm{n} / \mathrm{a}$ & Fall 2008 & 14.0801 \\
\hline Journalism/Media Studies M & New & $11 / 29 / 2007$ & $\mathrm{n} / \mathrm{a}$ & Fall 2008 & 9.0401 \\
\hline History - R & New & $9 / 6 / 2007$ & $1 / 28 / 2009$ & Fall 2009 & 54.0101 \\
\hline Sociology - R & New & $9 / 6 / 2007$ & $1 / 28 / 2009$ & Fall 2009 & 45.1101 \\
\hline Government - R & New & $9 / 6 / 2007$ & $1 / 28 / 2009$ & Fall 2009 & 45.0901 \\
\hline Pharmacy - P & New & $6 / 12 / 2008$ & $1 / 28 / 2009$ & Fall 2010 & 51.2099 \\
\hline 6B. Graduate Degrees Awarded & 2004-2005 & 2005-2006 & $2006-2007$ & $2007-2008$ & 2008-2009 \\
\hline Master's and Specialist & 1,841 & 1,736 & 1,803 & 2,014 & 1810 \\
\hline Research Doctoral (Total) & 194 & 184 & 223 & 259 & 248 \\
\hline Professional Doctoral (Total) & 103 & 93 & 122 & 143 & 154 \\
\hline Medicine & 103 & 93 & 116 & 115 & 114 \\
\hline Law & 0 & 0 & 0 & 0 & 0 \\
\hline Pharmacy & 0 & 0 & 0 & 0 & 0 \\
\hline 6C. Graduate Degrees Awarded in & \multicolumn{5}{|c|}{ Areas of Strategic Emphasis: Specific degree programs will be identified } \\
\hline Areas of Strategic Emphasis & 2004-2005 & 2005-2006 & 2006-2007 & $2007-2008$ & 2008-2009 \\
\hline Education & 105 & 87 & 79 & 94 & 126 \\
\hline Health Professions & 390 & 384 & 426 & 418 & 497 \\
\hline $\begin{array}{c}\text { Science, Technology, Engineering, } \\
\text { and Math }\end{array}$ & 476 & 425 & 445 & 535 & 528 \\
\hline Security \& Emergency Services & 15 & 13 & 6 & 23 & 50 \\
\hline Globalization & 40 & 37 & 42 & 46 & 41 \\
\hline Regional Workforce Needs & 434 & 373 & 389 & 422 & 424 \\
\hline $\begin{array}{c}\text { TOTAL: Areas of Strategic } \\
\text { Emphasis }\end{array}$ & 1,460 & 1,319 & 1,387 & 1,538 & 1,666 \\
\hline 6D. Licensure Pass Rates & 2004 & 2005 & 2006 & 2007 & 2008 \\
\hline
\end{tabular}




\begin{tabular}{|c|c|c|c|c|c|}
\hline \multicolumn{6}{|c|}{7 - Research and Economic Development Data } \\
\hline $\begin{array}{l}\text { 7A. Research and Development } \\
\text { Expenditures }\end{array}$ & 2003-2004 & 2004-2005 & $2005-2006$ & 2006-2007 & 2007-2008 \\
\hline $\begin{array}{c}\text { Federally Financed Academic } \\
\text { Research and Development } \\
\text { Expenditures (As Reported in NSF } \\
\text { Surveys) }\end{array}$ & \multirow{3}{*}{\multicolumn{5}{|c|}{$\begin{array}{l}\text { Development/ Research data is a USF system-wide function. } \\
\text { Consolidated system data is only available at this time. }\end{array}$}} \\
\hline $\begin{array}{l}\text { Total Academic Research and } \\
\text { Development Expenditures (As } \\
\text { Reported in NSF Surveys) }\end{array}$ & & & & & \\
\hline $\begin{array}{c}\text { Total Academic Research and } \\
\text { Development Expenditures Per Full-- } \\
\text { Time, Tenured, Tenure-Earning } \\
\text { Faculty Member }\end{array}$ & & & & & \\
\hline $\begin{array}{l}\text { 7B. Other Research and Economic } \\
\text { Development Outcomes [for Entire } \\
\text { University] }\end{array}$ & 2003-2004 & 2004-2005 & 2005-2006 & 2006-2007 & 2007-2008 \\
\hline Invention Disclosures Received & 138 & N/A & 109 & 110 & 139 \\
\hline Total U.S. Patents Issued & 22 & 23 & 29 & 31 & 31 \\
\hline $\begin{array}{l}\text { Patents Issued Per 1,000 Full-Time, } \\
\text { Tenure and Tenure-Earning Faculty }\end{array}$ & 22 & 20 & 24 & 26 & 26.4 \\
\hline $\begin{array}{l}\text { Total Number of Licenses/Options } \\
\text { Executed }\end{array}$ & 11 & 20 & 21 & 23 & 28 \\
\hline Total Licensing Income Received & $\$ 1,357,725$ & $\$ 1,548,818$ & $\$ 1,704,025$ & $\$ 2,099,712$ & $\$ 1,831,000$ \\
\hline Jobs Created By Start-Ups in Florida & \multicolumn{5}{|c|}{$\begin{array}{c}\text { Data collection methodology still under discussion. (See } \\
\text { endnote.) }\end{array}$} \\
\hline
\end{tabular}


7C. Centers of Excellence (Please complete for each Center of Excellence)

Name of Center of Excellence:

From First

Year Up To

Most

Recent Year

Most

Recent

Research Effectiveness

Competitive Grants Applied For and Received

Total Research Expenditures

Publications in Refereed Journals From Center Research

Professional Presentations Made on Center Research

Invention Disclosures Filed and Issued

Technologies Licensed and Revenues Received

Collaboration Effectiveness

Collaborations with Other Postsecondary Institutions

Collaborations with K-12 Education Systems/Schools

Collaborations with Private Industry

Students Supported with Center Funds

Students Graduated

Job Placements of Graduates Upon Leaving the Center

Economic Development Effectiveness

Business Start-Ups in Florida

Jobs Created and Jobs Saved in Florida

Specialized Industry Training and Education

Dollars Acquired from Venture Capitalists and Other Investments

Center of Excellence Narrative Comments [Most Recent Year]

USF System-wide data is only available at this time

Insert additional pages, as needed for additional Centers. 


\section{D. Commercialization Assistance Grants}

\section{Narrative Comments [Most Recent Year]}

(Limit to a maximum of $1 / 2$ page per grant.)

USF Phase I: Early Stage RAID $(\$ 50,000)$ A no cost extension was received for this project.

Program Setup and Selection: Initial review of the USF portfolio was conducted to develop a short list of technologies to evaluate for inclusion in the program. The list was narrowed to 5 potential technologies. Interviews were conducted with faculty to discuss interest in participation, additional scientific considerations, and the process moving forward if their technology is selected.

Subcontractor Evaluation and Selection: Several potential contractors for training and development of the RAID applications were contacted by phone, email, and in person. The contractors experience and expertise were evaluated. Process, cost, and scope of the project were discussed. At least two applications should be possible based on initial discussions if USF is actively involved in the process and dedicates a graduate student in the faculty lab who worked on the project and internal staff to work closely with external contractors. The contractor was narrowed to SRI. Terms for the engagement were negotiated and agreed to. Two technologies were selected and initial efforts begun to submit one application by the August Deadline for cancer therapeutic compounds. Initial drafting for the next deadline has been started on the second application. Optimistic that there is a possibility of more than two applications as a result of this important grant.

USF Phase II: Platinum Compounds $(\$ 50,000)$

Matching Funds and Compound Synthesis: Contract is in place with external university to synthesize the primary compounds and matching funds are being expended. A no cost extension was granted on the research contract. The first and second scientific reports were received under the matching funds grant. Satisfactory quantity and quality of compounds has not yet been achieved for the next level of studies required. Additional interaction with former USF faculty members and contract scientists ongoing. We remain optimistic that there will be a positive result from the synthesis experiments. Upon completion of synthesis, business plan will be initiated.

Additional grant programs with commercialization focus:

Insert additional pages, as needed for additional grants. 
8 - Voluntary Support of Higher Education*

Endowment Market Value (in 2009 Dollars)

Annual Gifts Received (\$ Amount)

Percentage of Graduates Who Are Alumni Donors
Development/Research data is a USF system-wide function. Consolidated system data is only available at this time.

* Data will be provided by Board staff for institutions that have reported said data through the NACUBO Endowment Study and the CAE Voluntary Support of Education (VSE) Survey.

\section{[INCLUDE ADDITIONAL BACKGROUND DATA ASSOCIATED WITH GRAPHS INCLUDED FOR GOAL \#4.]}

\section{ENDNOTES:}

- Currently, teacher certification examination pass rates are reported for program completers only, resulting in a $100 \%$ pass rate (because state-approved programs require passage of the certification exams for completion). Engineering, accounting, architecture, and other professional licensure data, gathered by the respective licensing boards and housed within the Department of Business and Professional Regulation, are not currently formatted and do not contain sufficient information to match to SUS data. Such a match is necessary to develop metrics reflecting pass rates for graduates in those fields. Board of Governors staff will work with individuals from the appropriate agencies to try to get data in the needed format.

- Board staff are continuing to work with the SUS Technology Transfer Directors to determine the best way to capture consistent information regarding Jobs Created By Start-Ups in Florida in a cost-effective manner.

\section{[Additional definition information will be added to final document.]}


9. Progress on Other Primary Institutional Goals and Metrics As Outlined in the University Work Plan

$P$ rovide a report on progress to date on three - five other primary university goals and metrics that were identified in the institution's last annual work plan/proposal.

[NOTE: In 2009, universities may only be able to identify goals and metrics or report on progress on institutional strategic planning goals already in place.]

SEE WORD DOCUMENT FOR NARRATIVE 